\title{
Redefinition of the Ligurian Units at the Alps-Apennines junction (NW Italy) and their role in the evolution of the Ligurian accretionary wedge: constraints from mélanges and broken formations
}

\author{
Edoardo Barbero $^{1 *}$, Andrea Festa ${ }^{2}$, Emilio Saccani ${ }^{1}$, Rita Catanzariti ${ }^{3}$ \& \\ Roberta D'Onofrio ${ }^{1}$ \\ ${ }^{1}$ Dipartimento di Fisica e Scienze della Terra, Università di Ferrara, Via Saragat, 1, 44122 Ferrara, Italy \\ ${ }^{2}$ Dipartimento di Scienze della Terra, Università di Torino, Via Valperga Caluso, 35, 10125 Torino, Italy \\ ${ }^{3}$ Istituto di Geoscienze e Georisorse, CNR - Consiglio Nazionale delle Ricerche, Pisa, Italy \\ (D) EB, 0000-0003-0247-0770; AF, 0000-0001-5325-0263; ES, 0000-0001-9879-2795; RC, 0000-0002-6408-0543; RD, \\ 0000-0002-5091-2927 \\ * Correspondence: edoardobarbero91@gmail.com
}

\begin{abstract}
We document that the undifferentiated chaotic Ligurian Units of the Monferrato-Torino Hill sector (MO-TH) at the Alps-Apennines junction consist of three different units that are comparable with the Cassio, Caio and Sporno Units of the External Ligurian Units of the Northern Apennines. Their internal stratigraphy reflects the character of units deposited in an ocean-continent transition (OCT) zone between the northwestern termination of the Ligurian-Piedmont oceanic basin and the thinned passive margin of Adria microcontinent. The inherited wedge-shaped architecture of this OCT, which gradually closed toward the north in the present-day Canavese Zone, controlled the Late Cretaceous-early Eocene flysch deposition at the trench of the External Ligurian accretionary wedge during the oblique subduction. This favoured the formation of an accretionary wedge increasing in thickness and elevation toward the SE, from the MO-TH to the Emilia Northern Apennines. Our results therefore provide significant information on both the palaeogeographical reconstruction of the northwestern termination of the Ligurian-Piedmont oceanic basin and the role played by inherited along-strike variations (stratigraphy, structural architecture and morphology) of OCT zones in controlling subduction-accretionary processes.
\end{abstract}

Supplementary material: A spreadsheet with X-ray fluorescence spectrometry and inductively coupled plasma mass spectrometry whole-rock major and trace element composition of mantle peridotites, and photomicrographs of mantle peridotites are available at https://doi.org/10.6084/m9.figshare.c.4519643

Received 15 February 2019; revised 21 May 2019; accepted 24 May 2019

Several interlinked geological, physical and mechanical factors are thought to control the localization and style of subductionaccretionary processes, and the shape and dynamics of the frontal wedge at convergent margins. The main factors are as follows: (1) the structural and palaeogeographic inheritance from ancient oceanic basins and associated continental margins (e.g. nature, physiography, internal tectonostratigraphic architecture, etc.; see Malatesta et al. 2013; Spalla et al. 2014; Balestro et al. 2018; Marotta et al. 2018; Roda et al. 2018; Festa et al. 2019a, and references therein); (2) the thickness of the subducted trench sediments; (3) the obliquity of the subduction; (4) the plate convergence rate (e.g. Clift \& Vannucchi 2004; Vannucchi et al. 2008; Remitti et al. 2011; Heuret et al. 2012; Malatesta et al. 2013; Festa et al. 2018; Geersen 2019). The interplay and combination of all or some of these factors played a significant role in the tectonic evolution of the Alps-Apennines orogenic system, which was controlled at regional scale by the oblique convergence and counterclockwise rotation of the Adria microplate relative to the European plate (e.g. Rosenbaum et al. 2002; Molli \& Malavieille 2011; Argnani 2012; Zanchetta et al. 2012). This oblique convergence drove the Late Cretaceous-early Cenozoic subduction of the Northern Alpine Tethys (Ligurian-Piedmont Ocean), the diachronous (i.e. younging from north to south) continental collision between the European continental margin and the Adria microplate (African plate), and the subsequent intra-continental deformation (e.g. Polino et al. 1990; Marroni et al. 2010, 2017; Molli et al. 2010; Mosca et al. 2010; Remitti et al. 2011; Festa et al. 2013, $2019 a$ ).

In the sector of the Alps-Apennines junction (i.e. the Monferrato and Torino Hill in NW Italy, MO-TH hereafter; Fig. 1), the Ligurian Units, which represent the remnants of the deposition at the oceancontinent transition (OCT) between the Ligurian-Piedmont Ocean and the thinned passive margin of Adria, are unconformably overlain by a middle-upper Eocene-upper Miocene episutural succession, represented by the Tertiary Piedmont Basin (e.g. Mutti et al. 1995; Piana \& Polino 1995). In contrast to the Ligurian Units in the Northern Apennines (e.g. Bettelli et al. 1989; Vescovi et al. 1999; Marroni et al. 2001, 2010; Principi et al. 2004; Marroni \& Pandolfi 2007; Catanzariti \& Perilli 2011, 2015; Vercesi et al. 2015), the Ligurian Units of the MO-TH were always described as an upper Cretaceous-Paleogene(?) undifferentiated chaotic complex or mélange (i.e. 'undifferentiated complex' sensu Bonsignore et al. 1969; 'La Pietra chaotic complex' sensu Dela Pierre et al. 2003; Festa et al. 2009). As a consequence, a characterization and distinction of the tectonostratigraphic architecture of these units is lacking. Therefore, a systematic and detailed investigation of the Ligurian Units in the MO-TH may provide significant constraints for the reconstruction of the tectonostratigraphic architecture of the OCT zone at the Western Alps-Northern Apennines junction (i.e. the 'Ligurian knot' Auct.).

This paper aims to define for the first time the tectonostratigraphic setting of the chaotic Ligurian Units in the MO-TH through 


\section{E. Barbero et al.}

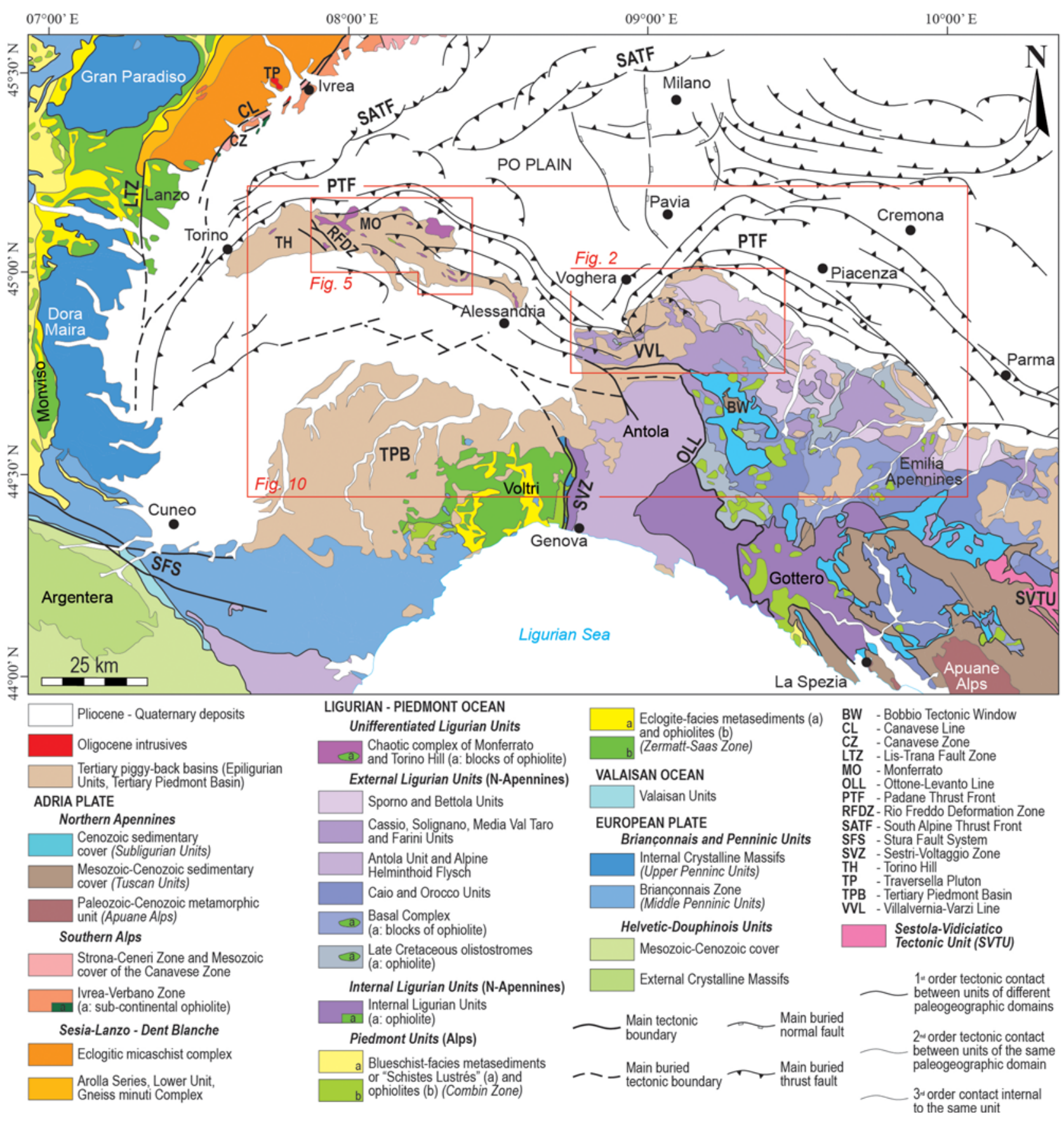

Fig. 1. Structural sketch map of northwestern Italy (modified from Balestro et al. 2015). The location of the studied areas (Figs 2 and 5) is also shown.

multidisciplinary and multiscale, field- and laboratory-based stratigraphic and structural studies, as well as petrographic and geochemical analyses of mantle rocks included within several chaotic rock units (i.e. mélanges and broken formations; see Festa et al. 2019b, for the mélange terminology used here). The tectonostratigraphic features of the chaotic Ligurian Units of the MO-TH will then be compared with those of the External Ligurian Units in the Northern Apennines to discuss the meaning of the difference in the tectonostratigraphic architecture of distinct sectors of OCT zone (i.e. the External Ligurian Units depositional basin). Finally, we discuss the role of the OCT zone tectonostratigraphic architecture as structural and palaeogeographical inheritance in controlling the shape and tectonostratigraphic evolution of the External Ligurian accretionary wedge during Late Cretaceous-middle Eocene subduction stages. This study presents, therefore, useful observations to better constrain the subduction-accretionary and collisional stages in the Alps and Apennines belts, as well as in similar orogenic belts worldwide.

\section{Regional geological setting}

The Ligurian Units in the Northern Apennines (Fig. 1) consist of Mesozoic and early Cenozoic sedimentary successions and Jurassic ophiolites, and collectively represent the remnants of the LigurianPiedmont Ocean, which evolved between the European plate and the Adria microplate (e.g. Coward \& Dietrich 1989; Principi et al. 2004; Marroni et al. 2010). Close to the study sector, the Adria microplate succession is well exposed in the Canavese Zone (South Alpine units of the Inner Western Alps; Fig. 1). Here, the tectonic juxtaposition of slices of sub-continental mantle serpentinites with a PaleozoicMesozoic succession comparable with that of the Lombardian Basin (e.g. Festa et al. 2019a, and references therein) suggests that the Canavese Zone may represent the tectonically disrupted remnant of the thinned passive margin of the Adria microcontinent at the OCT zone with the Ligurian-Piedmont Ocean basin (e.g. Elter et al. 1966; Ferrando et al. 2004; Barnes et al. 2014; Festa et al. 2019a). 


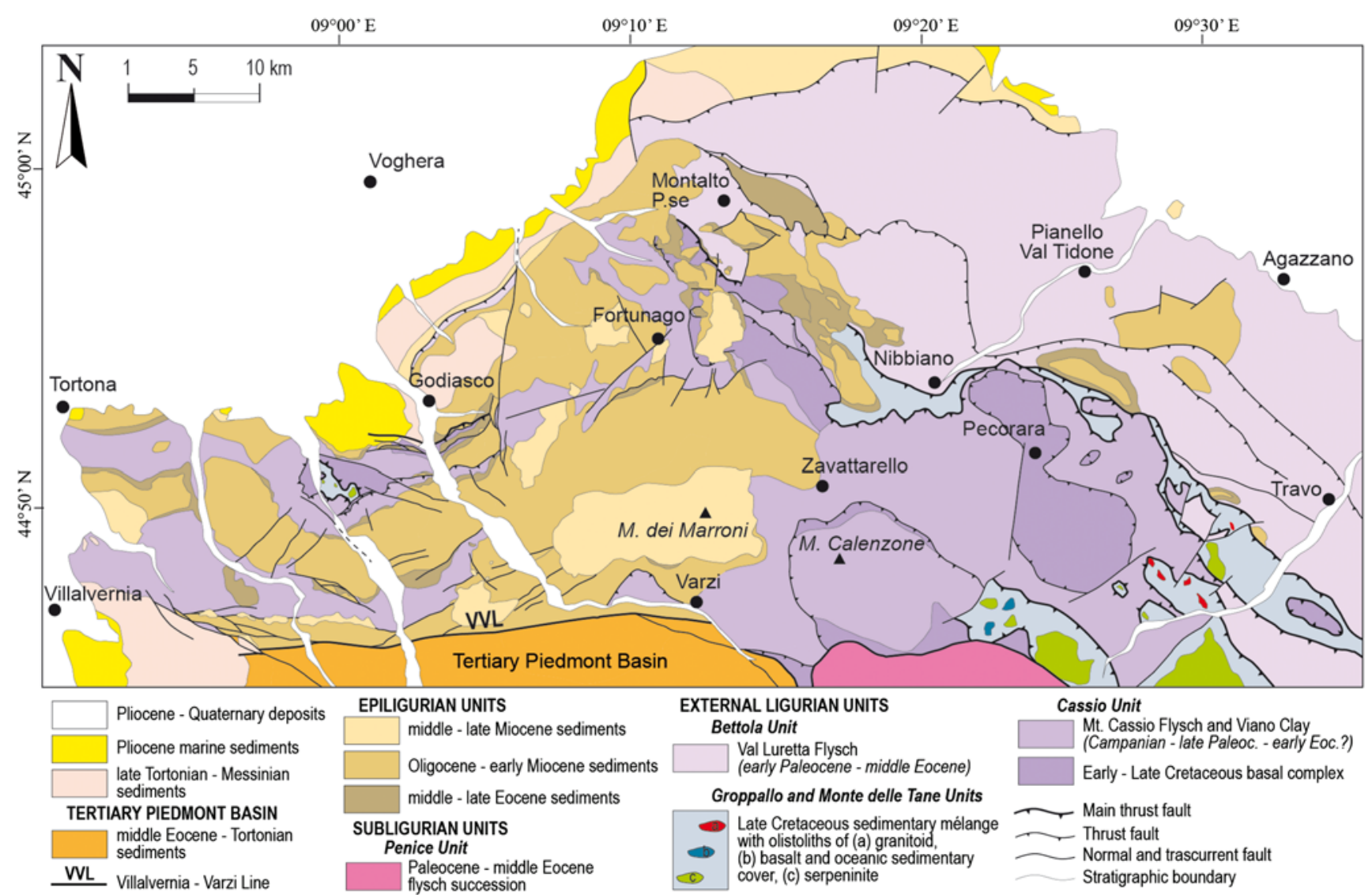

Fig. 2. Simplified geological-structural map of the Voghera sector showing the stratigraphic and structural relationships between the External Ligurian and the overlying Epiligurian Units (modified from Vercesi et al. 2005; Festa et al. 2015; Barbero et al. 2017).

The Ligurian Units of the Northern Apennines (e.g. Elter et al. 1966; Elter 1975; Marroni \& Pandolfi 2007) are classically distinguished as the Internal Ligurian Units and External Ligurian Units. The Internal Ligurian Units consist of a Jurassic ophiolitic sequence and related Middle Jurassic-lower Paleocene sedimentary cover, representative of the oceanic lithosphere of the LigurianPiedmont Ocean (e.g. Marroni \& Pandolfi 1996, 2007; Piccardo et al. 2001; Principi et al. 2004). Accordingly, the Internal Ligurian Units mantle peridotites have a depleted geochemical signature (e.g. Rampone et al. 1996, 2019; Sanfilippo \& Tribuzio 2011). In contrast, the External Ligurian Units consist of thick Lower Cretaceous-middle Eocene pelagic and turbiditic successions detached from their pre-Cretaceous substratum, and are interpreted as deposited within the OCT zone existing between the LigurianPiedmont Ocean basin and the thinned continental margin of Adria (e.g. Bettelli et al. 1989; Marroni et al. 1998, 2001; Vescovi et al. 1999). In the Northern Apennines, the External Ligurian Units are differentiated into several units (e.g. Caio, Orocco, Groppallo, Antola, Cassio, Farini, Bettola, Sporno Units, Fig. 1) based on (1) lithostratigraphic features of their Lower-Upper Cretaceous units (i.e. their Basal Complexes), (2) stratigraphy and age of the overlying Helminthoid Flysch type succession and (3) present-day structural position within the accretionary wedge (e.g. Elter \& Marroni 1991; Vescovi 1993; Vescovi et al. 1999; Marroni et al. 2001; Catanzariti \& Perilli 2011, 2015; Vercesi et al. 2015). Based on the characteristics of the Basal Complexes, Marroni et al. (2001) have subdivided the External Ligurian Units into groups, which reflect a distinct palaeogeographical position within the OCT zone (i.e. the 'ocean-ward' Western and 'continent-ward' Eastern External Ligurian units). The Basal Complexes of the Western External Ligurian units (e.g. Casanova Complex; see Elter et al. 1991) include abundant blocks of oceanic-derived rocks (i.e. mainly lherzolites, with basalts and subordinate gabbros), as well as minor continental-derived rocks (i.e. granitoids and granulites; see Marroni \& Tribuzio 1996; Montanini 1997; Marroni et al. 1998). These upper mantle peridotites represent slices of the fertile subcontinental lithospheric mantle exhumed at the OCT zone during the early stage of rifting of the Ligurian-Piedmont Ocean (e.g. Beccaluva et al. 1984; Rampone et al. 1995; Piccardo et al. 2001; Tribuzio et al. 2004; Montanini et al. 2006, 2012; Piccardo 2010; Saccani et al. 2015). The Basal Complexes of the Eastern External Ligurian Units display turbiditic and conglomerate-bearing successions sourced from the Adria continental margin (e.g. Scabiazza Sandstones and Salti del Diavolo Conglomerates; see Elter et al. 1966; Vescovi et al. 1999; Marroni et al. 2001; Bracciali et al. 2007), as well as tectonic slices of Triassic-Jurassic age, comparable with the South Alpine sedimentary succession (e.g. Vercesi \& Cobianchi 1998; Panini et al. 2002; Codegone et al. 2012).

In contrast to the Northern Apennines, the Ligurian succession in the MO-TH is described as an Upper Cretaceous-middle Eocene undifferentiated chaotic complex (or mélange) consisting of a varicoloured shaly matrix including different types of blocks (i.e. 'undifferentiated complex' sensu Bonsignore et al. 1969; 'La Pietra chaotic complex' sensu Dela Pierre et al. 2003; Festa et al. 2009). Elter et al. (1966) and Bonsignore et al. (1969) have suggested a correlation of the Albian-Cenomanian 'Lauriano Complex' and the Maastrichtian 'Monteu da Po Flysch' (i.e. parts of the 'undifferentiated complex') with the Basal Complexes and the Monte Cassio Flysch of the External Ligurian Units of the Northern Apennines, respectively. However, the distinction of these units on geological maps was only made much later by Festa \& Codegone (2013) and Festa et al. (2013).

Since the Late Cretaceous to middle Eocene and prior to the continental collision, the Internal and External Ligurian Units were 


\section{E. Barbero et al.}

deformed and incorporated into the Alpine accretionary wedge formed by the east-dipping subduction of the Ligurian-Piedmont Ocean below Adria (e.g. Principi \& Treves 1984; Vescovi et al. 1999; Marroni et al. 2004). During the earlier middle Eocene, the establishment of a west-dipping 'Apenninic' subduction formed an ENE-facing Ligurian accretionary wedge (i.e. the protoApennines), which progressively involved the External Ligurian Units and the thinned continental margin of Adria. As a result, the External Ligurian Units were underthrust below the Internal Ligurian Units (e.g. Marroni et al. 2010).

Since the middle Eocene, wedge-top basin successions (i.e. the Epiligurian Units in the Northern Apennines and the Tertiary Piedmont Basin in the internal part of the Western Alps) unconformably overlaid the Ligurian accretionary complex. The Tertiary Piedmont Basin, where the MO-TH is located, represents an episutural basin, sealing the tectonic suture between the Alps and Apennines (e.g. Mutti et al. 1995; Piana \& Polino 1995; Piana 2000; Mosca et al. 2010; Molli et al. 2010). The present-day structural setting of both the MO-TH and the Northern Apennines then resulted by different main tectonic stages that developed after the middle Eocene (e.g. Piana 2000; Panini et al. 2002, 2006; Dela Pierre et al. 2003; Festa et al. 2005, 2009, 2015; Festa \& Codegone 2013; Barbero et al. 2017).

\section{The External Ligurian Units in NW Apennines: the Voghera sector}

Three units of the External Ligurian Units, which are characterized by different stratigraphic successions, are tectonically juxtaposed in the Voghera Sector of the NW Apennines (Fig. 2). They are the Cassio, Groppallo and Bettola Units.

\section{The Cassio Unit succession}

This succession is characterized by highly disrupted Basal Complexes (Scabiazza Sandstone and Argille Varicolori), followed by an upper Campanian-upper Paleocene flysch succession (Figs 2 and 3). The Scabiazza Sandstone is late Albian-Santonian in age (CC9/14 zone; Barbero et al. 2017) and consists of a broken formation with tabular to irregular bed fragments of micaceous sandstones embedded into a pelitic matrix (Fig. 4a). It passes upward to the Argille Varicolori (Santonian-Campanian), which represent a highly disrupted broken formation with a block-inmatrix internal organization, deriving from layer-parallel extension and disruption of an originally coherent stratigraphic sequence of varicoloured shales (i.e. the matrix) alternating with beds of limestone, manganiferous siltstone and minor sandstone (Fig. 4b). Tens of metres thick Salti del Diavolo conglomerates (early Campanian in age, CC18/19 zone; Barbero et al. 2017) are interbedded within the Argille Varicolori. Their clasts consist of predomiant carbonate rocks and minor micaschists, gneisses, quartzites, granulites, pinkish granites and diorites, which show a close affinity with the lithostratigraphic succession of the Adria passive margin (i.e. South Alpine domain; see Elter et al. 1966).

The Basal Complexes are followed by the Monte Cassio Flysch $(<500 \mathrm{~m}$ in thickness), through a tectonically reworked stratigraphic contact. The Monte Cassio Flysch consists of alternating beds of clayey marls and carbonate-rich calcareous-marly turbidites, which range from decimetres to metres in thickness (Fig. 4c) and define an upper Campanian succession (CC21/23 zone; see Barbero et al. 2017) (Figs 2 and 3). This succession increases in thickness from 250 to $500 \mathrm{~m}$ toward the ESE. The Cassio Unit succession closes upward with the Viano Clays (late Maastrichtian-late Paleoceneearly Eocene?; Fig. 3), which are about $300 \mathrm{~m}$ in thickness and consist of alternating layers of claystone, thin beds of sandstone and

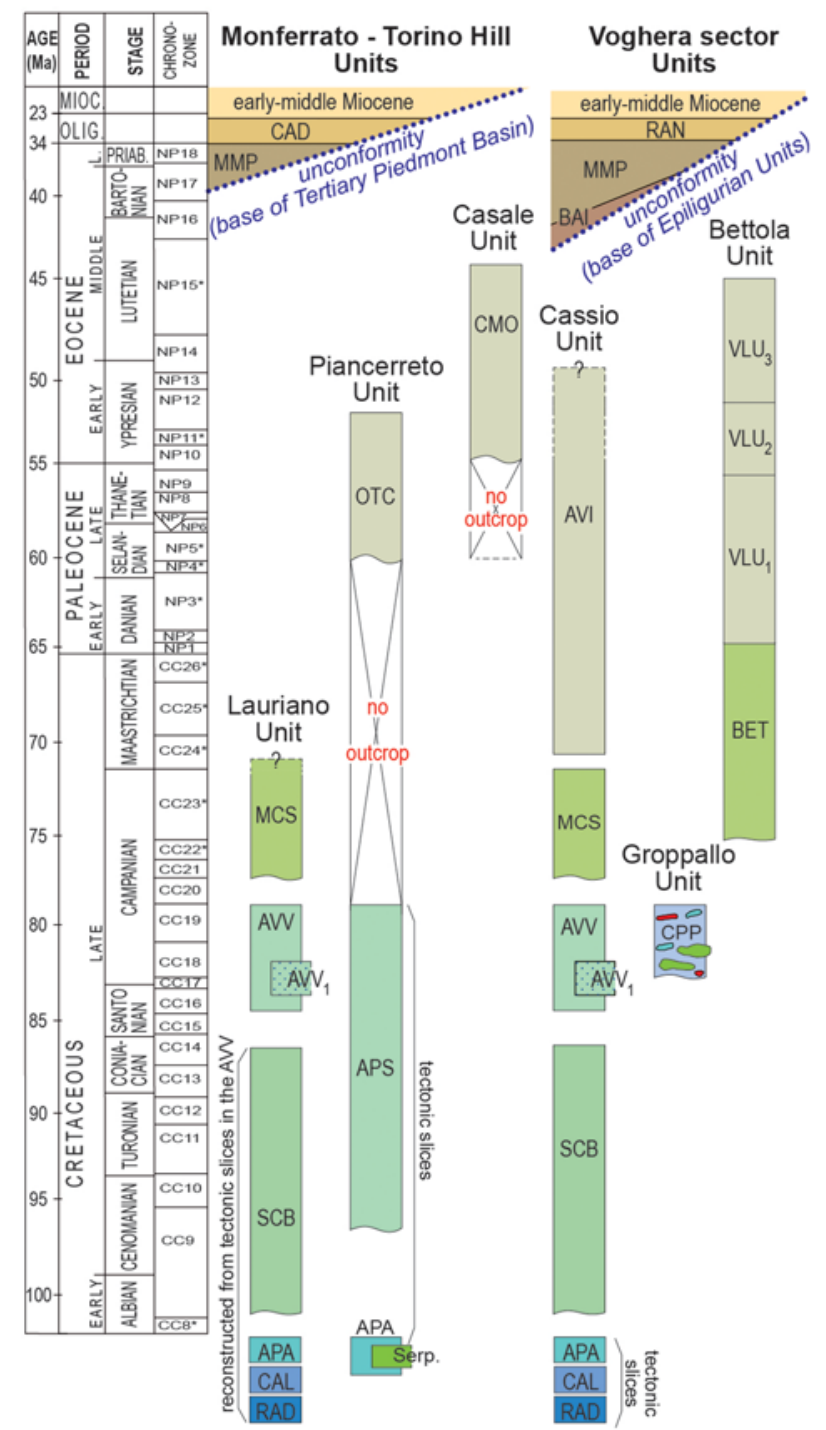

Fig. 3. Stratigraphic columns of External Ligurian Units in the Monferrato-Torino Hill and Voghera sectors. APA, Palombini Shale; APS, Passo della Sisa Clay equivalent; AVI, Viano Shale; AVV, Argille Varicolori; $\mathrm{AVV}_{1}$, Salti del Diavolo conglomerates; BAI, Baiso argillaceous breccias; BET, Bettola Flysch; CAD, Cardona Fm; CAL, Calpionella Limestone; CMO, Casale Monferrato Flysch; CPP, Parcellara Complex (sedimentary mélange); MCS, Monte Cassio Flysch; MMP, Monte Piano marls; OTC, Ottiglio clay; RAN, Ranzano Fm; RAD, radiolarian chert; SCB, Scabiazza sandstone; Serp., serpentinized lherzolite; VLU 1 , Poviago Mbr, VLU 2 , Monteventano Mbr; VLU $U_{3}$, Genepreto Mbr of Val Luretta Fm (see also Vercesi et al. 2005; Festa et al. 2009, 2015; Festa \& Codegone 2013; Barbero et al. 2017).

decimetres-thick limestone beds. The last gradually decrease in abundance upward and disappear in the upper part of the sequence.

\section{The Groppallo Unit succession: the ophiolite-bearing sedimentary mélange}

This consists of the Pietra Parcellara Complex, which is a sedimentary mélange with a block-in-matrix fabric (Figs 2 and 3; see also Vercesi et al. 2005, 2015; Barbero et al. 2017), showing a Santonian-early Campanian age (CC18/19; see Barbero et al. 2017) and a gradual increase in thickness from $150 \mathrm{~m}$ to more than $300 \mathrm{~m}$ toward the ESE and SE. Heterogeneous blocks, up to $200 \mathrm{~m}$ in size, are randomly distributed in a matrix of coarse-grained ophiolitic sandstones and polymictic argillaceous breccias. Larger blocks (olistoliths) mainly consist of ultramafic rocks (i.e. spinel-lherzolite; 

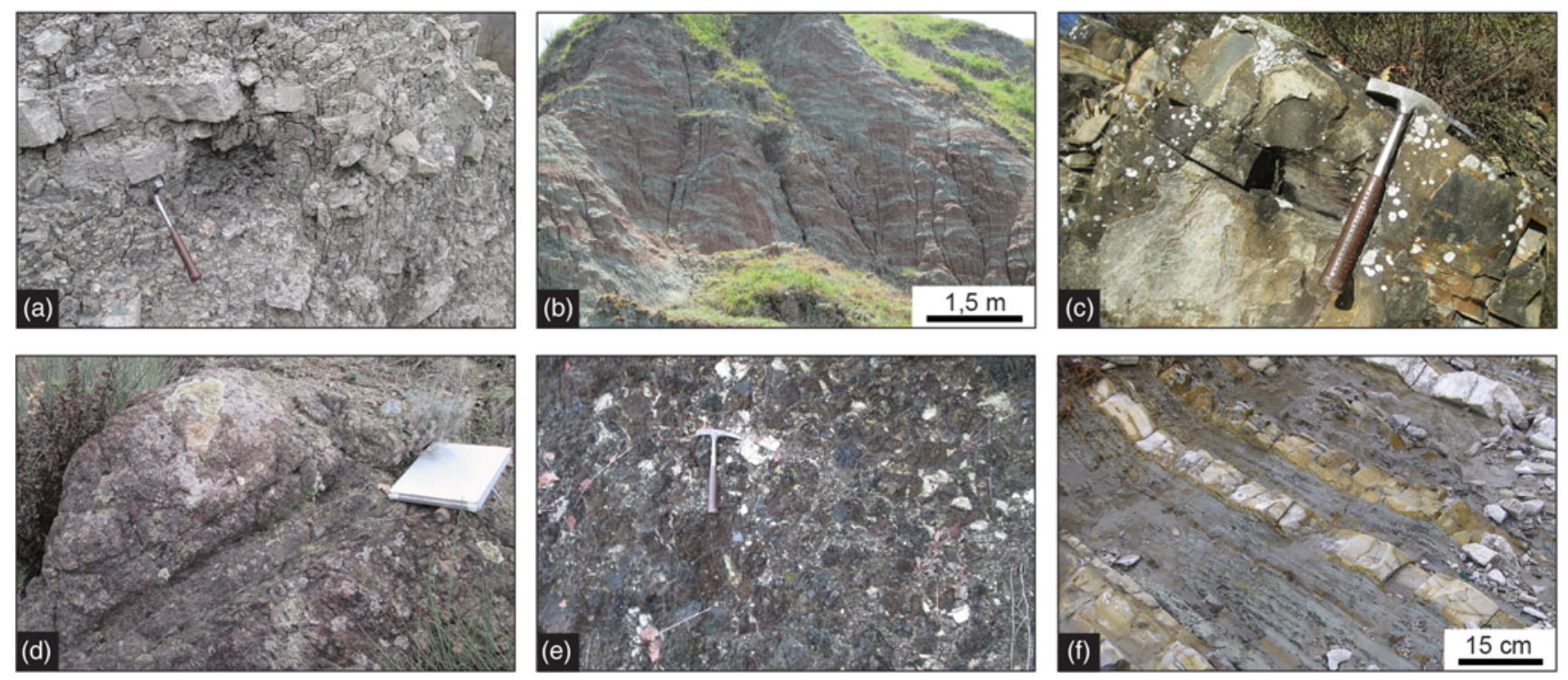

Fig. 4. Field occurrences of the External Ligurian Units in the Voghera sector. Cassio Unit: (a) highly disrupted chaotic succession (broken formation) of the Scabiazza Sandstone; hammer for scale; (b) disharmonic to isoclinal and transposed folds in the varicoloured shale of the Argille Varicolori; (c) closeup of calcareous turbidites of the Monte Cassio Flysch; hammer for scale. Groppallo Unit: (d) close-up view of a spinel lherzolite olistolith enclosed within the Pietra Parcellara Complex; folder for scale; (e) clast-supported debris flow of polymictic clasts of ultrabasic rocks (dark green to reddish in colour) and oceanic cover succession (whitish in colour) of the Pietra Parcellara Complex; hammer for scale. Bettola Unit: (f) alternating shaly marls and calcareous turbidites of the Val Luretta Formation.

Fig. 4d), locally intruded by small gabbro bodies, fragments of Upper Jurassic-Lower Cretaceous oceanic cover succession (Calpionella Limestone and Palombini Shale), and soft blocks of red to purple shales. The matrix shows marked lateral and vertical variability of facies between the following: (1) ophiolitic breccias, consisting mainly of angular clasts of ultramafic rock set in an unsorted coarse-grained ophiolitic matrix; (2) lenticular polygenetic breccias (Fig. 4e) derived from blocky- to hyper-concentrated flows, which show lateral and vertical transition to coarse-grained greenish sandstones; (3) blackish and reddish brecciated clays, including centimetre- to metre-sized clasts. Clasts, blocks and lithic fragments included in or forming the different matrix types are compositionally heterogeneous and consist of ultramafic rocks, gabbros, basalts, micritic limestones and minor radiolarian cherts (Fig. 4e).

\section{The Bettola Unit succession}

This is represented only by the Val Luretta Formation (early Paleocene-middle Eocene, NP2-NP15 zones; Vercesi et al. 2005; Figs 2 and 3), which consists of three superimposed members (Cobianchi et al. 1994, 1995) forming an 800-900 m thick succession (Figs 2 and 3). This succession is generally made of alternating layers of weakly deformed shale, well-bedded limestone and calcarenite in varying proportions. A distinctive feature of this formation is the occurrence in the lower member (the DanianThanetian Poviago member) of distinct thick beds of pinkish marls and calcarenites. The upper part of the formation (the ThanetianLutetian Monteventano and Genepreto members) is characterized by the increasing abundance of greyish and whitish marls alternating with thick beds of limestone (Fig. 4f), as well as by the lack of the pinkish marls. A Helminthoid Flysch type (the late Campanian-Danian Bettola Flysch) represents the stratigraphic base of the Val Luretta Formation (Fig. 3; see, e.g. Vercesi et al. 2015, and references therein). In the light of further regional-scale correlations (see the section 'Redefinition of the External Ligurian Units in the MO-TH' section 5.1), it is noteworthy that no Basal Complexes can be stratigraphically associated with the Bettola Flysch.

\section{The External Ligurian Units in the Monferrato and Torino Hill}

We have distinguished three units within the previously undifferentiated La Pietra Chaotic Complex (sensu Dela Pierre et al. 2003): the Lauriano, the Piancerreto and the Casale Units (Figs 3 and 5).

\section{The Lauriano Unit succession}

The Lauriano Unit (Figs 3 and 5), which was correlated with the Cassio Unit by Festa \& Codegone (2013), consists of a highly chaotic succession represented by Santonian-Campanian varicoloured shales of the Basal Complexes (i.e. Argille Varicolori; see Elter et al. 1966; Festa et al. 2013), which are followed by a discontinuous and scattered upper Campanian-lower Maastrichtian (?) flysch (i.e. Monte Cassio Flysch; CC21/23 zone; see also Elter et al. 1966). The Argille Varicolori represent a highly disrupted broken formation, displaying a block-in-matrix fabric (Fig. 6a). The matrix consists of centimetres- to decimetres-thick layered varicoloured clays, enclosing 'native' blocks of limestone (Fig. 6a), manganiferous siltstone, and sandstone derived from disruption and fragmentation of an originally coherent succession. Along shear zones, tectonic blocks and slices of Cenomanian(?)-lower Campanian Scabiazza sandstones, Lower Cretaceous Palombini shales, Upper Jurassic-Lower Cretaceous Calpionella limestones and Jurassic radiolarian cherts are locally tectonically embedded within the Argille Varicolori, thus forming tectonic mélanges. These tectonic blocks allow us to define the nature of the unexposed portion of the Basal Complexes (see Elter et al. 1966; Festa et al. 2013). Similarly to the Voghera sector, the Salti del Diavolo Conglomerates (Fig. 6b) are intercalated within the Campanian Argille Varicolori of the Lauriano Unit (e.g. Elter et al. 1966; Bonsignore et al. 1969; Dela Pierre et al. 2003; Festa \& Codegone 2013). The lithology of the clasts (micaschist, gneiss, two-mica schist, diorite, post-Variscan granite, Permian volcanic rocks, Verrucano-type conglomerate, Triassic dolomite, radiolarian chert, Calpionella limestone, etc.) indicates that they can be generally reconciled to an Adria passive margin lithostratigraphy, 


\section{E. Barbero et al.}

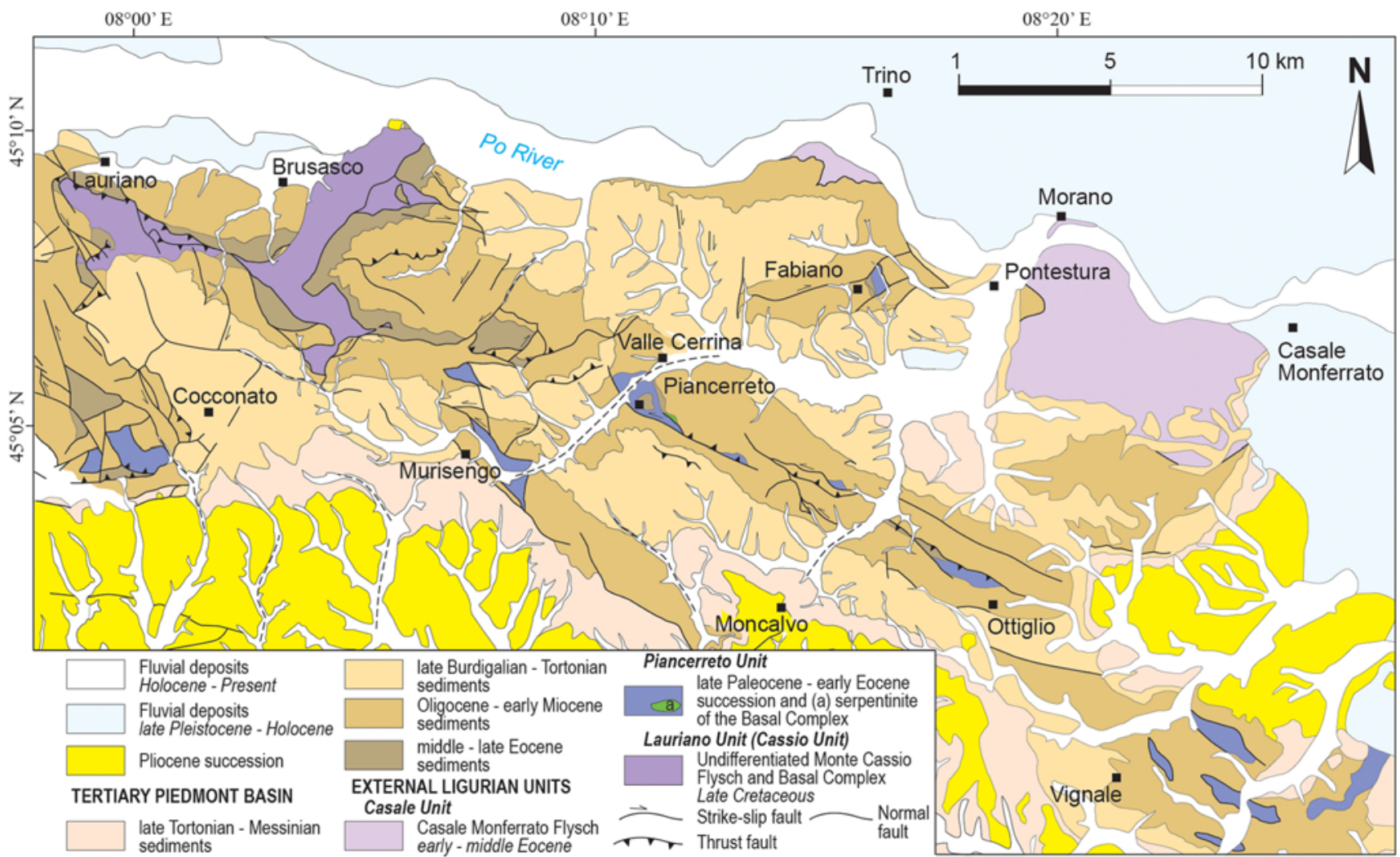

Fig. 5. Simplified geological-structural map of the Monferrato-Torino Hill sector, showing stratigraphic and structural relationships between the External Ligurian Units and the overlying Tertiary Piedmont Basin succession (modified from Bonsignore et al. 1969; Dela Pierre et al. 2003).

which is, in turn, similar to that of the Canavese Zone (see Elter et al. 1966; Festa et al. 2019a).

The upper Campanian-lower Maastrichtian(?) Monte Cassio Flysch (Fig. 6c) represents the youngest term of the succession. Although highly disrupted, field data suggest that it consists of a 250-400 m thick succession of alternating greyish and light brownyellowish hybrid arenite horizons $10-100 \mathrm{~cm}$ thick, thin calcareous turbidites and grey marl beds, up to decimetres thick. This flysch succession differs from that of the Voghera sector in the higher abundance of arenitic turbidites with respect to the calcareous ones.

\section{The Piancerreto Unit succession}

This consists of a highly disrupted broken formation (Figs 3 and 5), informally named the Ottiglio clay, made of greyish to dark greyish and locally brownish marl (Fig. 6e), alternating with grey calcareous
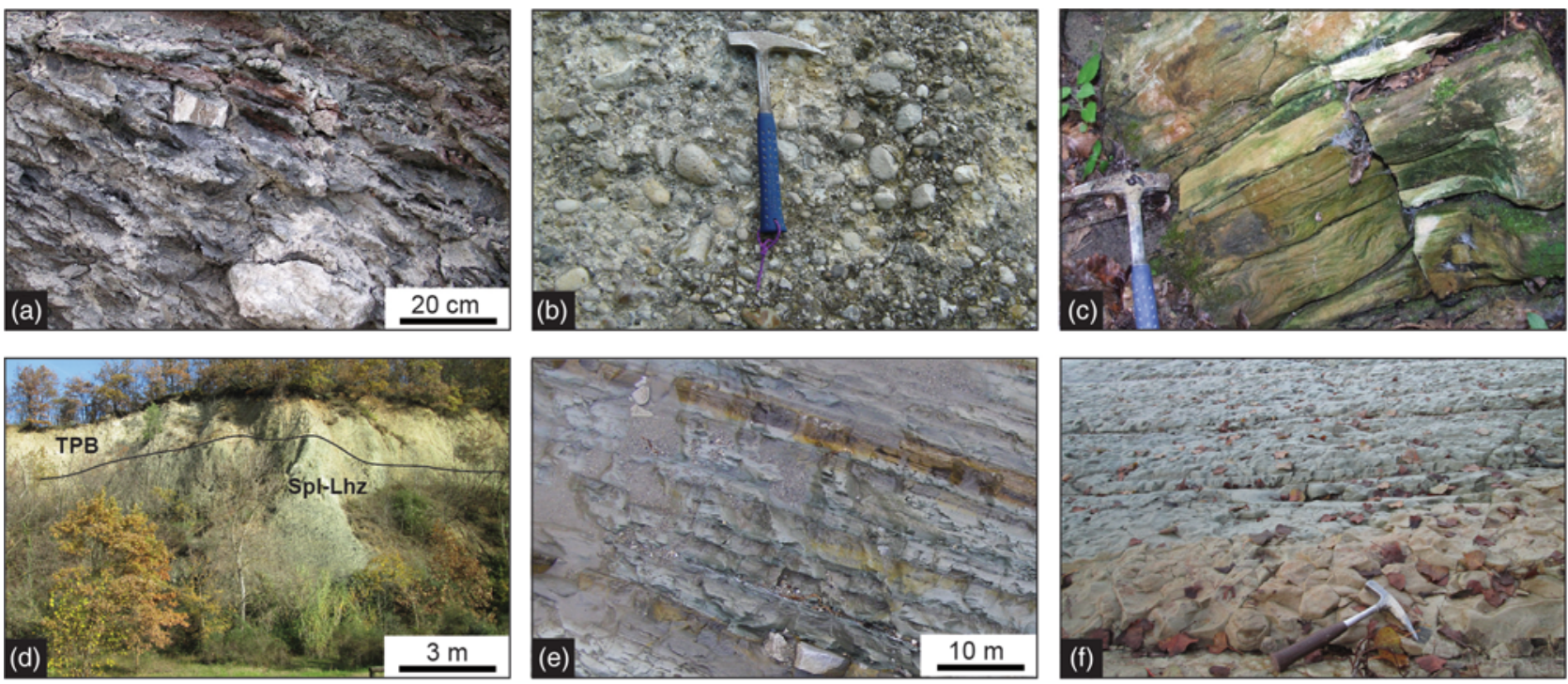

Fig. 6. Field occurrences of the External Ligurian Units in the Monferrato-Torino Hill sector. Lauriano Unit: (a) highly disrupted block-in-matrix fabric of the Argille varicolori defining a broken formation (courtesy of F. Coscarelli); (b) close-up view of the Salti del Diavolo conglomerates; hammer for scale; (c) light brown-yellowish hybrid turbiditic calcarenite of the Monte Cassio Flysch; hammer for scale. Piancerreto Unit: (d) panoramic view of the serpentinized lherzolite (Spl-Lhz) unconformably overlain by the Tertiary Piedmont Basin succession (TPB); (e) close-up view of the Ottiglio clay, showing greyish marls alternating with grey calcareous marls. Casale Unit: (f) greyish marls of the Casale Monferrato Flysch, hammer for scale. 
marl and yellowish to light brownish turbiditic sandstone and calcarenite. Analyses of calcareous nannofossils show late Paleocene to early Eocene taxa, allowing us to assign Thanetian (NP9 zone) and Ypresian (NP12 zone) ages for the uppermost part of the succession in the Ottiglio and Fabiano sectors, respectively.

Close to Piancerreto village, geological mapping constraints suggest that a hundreds of metres wide lenticular block of ultramafic rocks is tectonically juxtaposed with the Ottiglio clay (Figs 5 and 6d) and both are uncoformably sealed by the middle-upper Eocene to Oligocene lower part of the Tertiary Piedmont Basin succession (Monte Piano marls and Cardona Formation; see Fig. 6d). This block consists of brecciated serpentinized spinel-lherzolite. Basaltic blocks, now absent because of quarry activity, were previously associated with ultramafic rocks (see Sacco 1935; Elter et al. 1966). Similar lherzolites, ranging in size from metres to tens of metres, were also described as lenticular blocks embedded within the Palombini Shale and varicoloured clays (i.e. Argille varicolori) close to Piancerreto village, as well as to the SE of Cocconato (Sacco 1935; Elter et al. 1966; Fig. 5). In contrast to what observed in the Groppallo Unit, no trace of gravity-induced deposits (sedimentary mélanges) occurs within this unit.

\section{The Casale Unit succession}

The stratigraphic succession of the Casale Unit is represented only by the Casale Monferrato Flysch (sensu Bonsignore et al. 1969), which consists of greyish to brownish claystone alternating with thick beds of greyish marly limestones, calcarenites and micritic limestones (Figs 3 and 6f). Thick calcareous megaturbidites (up to $5-10 \mathrm{~m}$ in thickness) are now rarely exposed as a consequence of intense quarry activity during the last century. Nonetheless they were earlier documented as being characteristic of the lower part of the succession and they have been described as passing upward to greyish marls alternating with yellowish limestone in decimetresthick beds (e.g. Lovari 1912). The thickness of this stratigraphic succession can be estimated to be at least $c .600 \mathrm{~m}$. According to literature data, the age of the Casale Monferrato Flysch is earlymiddle Eocene (see Bonsignore et al. 1969; Dela Pierre et al. 2003).

\section{Petrography and geochemistry of ultramafic rocks}

The ultramafic rocks from both the Groppallo and Piancerreto Units consist of serpentinized lherzolites, showing spinel-facies mineral assemblages and porphyroclastic and mylonitic textures. The serpentinization degree ranges from 20 to $80 \%$ in volume, although many samples show relatively high degrees of alteration. The porphyroclastic varieties consist of elongated (up to $1 \mathrm{~cm} \mathrm{long}$ ) and deformed crystals of olivine, orthopyroxene and minor clinopyroxene, surrounded by a fine-grained (1 $\mathrm{mm}$ in size) aggregate of serpentine, chlorite and $\mathrm{Fe}-\mathrm{Ti}$ oxides, as well as minor relics of olivine, pyroxene and spinel. The mylonitic peridotites show an original porphyroclastic texture, where porphyroclasts are generally surrounded by a millimetre-spaced foliation marked by a finegrained aggregate of olivine and pyroxene, commonly pseudomorphosed by serpentine and chlorite, and $\mathrm{Fe}-\mathrm{Ti}$ oxides as well as spinel. Microphotographs showing details of texture and mineral assemblages of these rocks are presented in the supplementary material.

The whole-rock chemical composition was determined by X-ray fluorescence (XRF) and inductively coupled plasma mass spectrometry (ICP-MS) at the Ferrara University. Analytical methods, as well as accuracy and precision, are as given by Saccani et al. (2018). Detailed results are presented in the supplementary material. The generally high degree of serpentinization of these rocks is reflected by high values of loss on ignition ( $\mathrm{LOI}=10.56-13.00 \mathrm{wt} \%$ ). However, the lack of correlation between the LOI values and most of

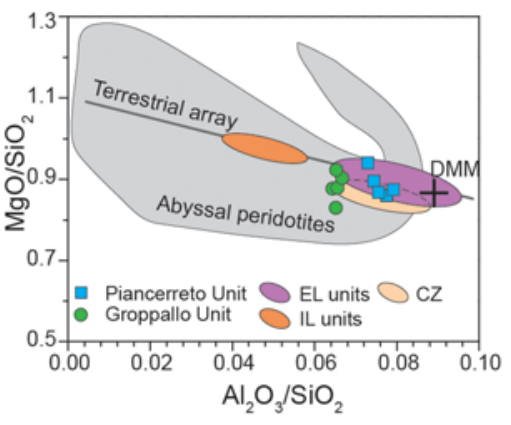

Fig. 7. Whole-rock $\mathrm{MgO} / \mathrm{SiO}_{2}$ v. $\mathrm{Al}_{2} \mathrm{O}_{3} / \mathrm{SiO}_{2}$ diagram for the blocks of upper mantle serpentinized lherzolites from the Groppallo and Piancerreto Units. Major element contents are recalculated to $100 \%$ on a loss on ignition free basis. The terrestrial array is from Jagoutz et al. (1979) and Hart \& Zindler (1986). The DMM (depleted mid-ocean ridge basalt mantle) is from Workman \& Hart (2005). Abyssal peridotite data are from PetDB database (http://www.earthchem.org). Fields showing the compositional variation of upper mantle lherzolites from the Canavese Zone (CZ), External Ligurian (EL) and Internal Ligurian (IL) Units are shown for comparison. Data source for Canavese Zone is Barnes et al. (2014); for External Ligurian Units, Rampone et al. (1995) and Montanini et al. (2012); for Internal Ligurian Units, Rampone et al. (1996).

the major element contents (e.g. $r^{2}$ LOI v. $\mathrm{MgO}=0.00 ; r^{2}$ LOI v. $\mathrm{TiO}_{2}=0.02 ; r^{2}$ LOI v. $\left.\mathrm{Al}_{2} \mathrm{O}_{3}=0.31\right)$ suggests that these elements, similarly to the most immobile elements (i.e. $\mathrm{Ni}, \mathrm{Cr}, \mathrm{V}$, $\mathrm{Zr}$, Y, rare earth elements (REE)), were not significantly mobilized even in the highly serpentinized lherzolites. The $\mathrm{MgO} / \mathrm{SiO}_{2} \mathrm{v} \cdot \mathrm{SiO}_{2} /$ $\mathrm{Al}_{2} \mathrm{O}_{3}$ diagram (Fig. 7) shows that these rocks plot within the compositional field for relatively fresh peridotites (Jagoutz et al. 1979; Hart \& Zindler 1986), further suggesting that the serpentinization induced very limited modification in terms of $\mathrm{MgO}, \mathrm{SiO}_{2}$ and $\mathrm{Al}_{2} \mathrm{O}_{3}$ contents.

Compared with the average composition of the depleted upper mantle peridotites from various ophiolites (see Saccani et al. 2017, and references therein), the spinel-lherzolites from both of the ophiolite-bearing units are characterized by relatively high $\mathrm{Al}_{2} \mathrm{O}_{3}$ (2.61-3.22 wt\%), $\mathrm{TiO}_{2}(0.08-0.13 \mathrm{wt} \%), \mathrm{Y}(1.81-2.97 \mathrm{ppm})$ and $\mathrm{Zr}(3.57-6.19 \mathrm{ppm})$, and relatively low Ni (1749-1965 ppm) and $\mathrm{Cr}\left(2244-2809\right.$ ppm) contents. The $\mathrm{Al}_{2} \mathrm{O}_{3}$ and $\mathrm{TiO}_{2}$ abundances display a well-defined negative correlation with $\mathrm{MgO}$ contents. These rocks display relatively high concentrations of heavy REE (HREE) with chondrite-normalized (normalizing values from Sun \& McDonough 1989) $\mathrm{Yb}$ composition $\left(\mathrm{Yb}_{\mathrm{N}}\right)$ in the range 1.24 1.97. They are slightly depleted in the light REE (LREE) with respect to medium REE (MREE) and HREE (Fig. 8a and b), as also exemplified by the moderately low $(\mathrm{La} / \mathrm{Yb})_{\mathrm{N}}$ and $(\mathrm{La} / \mathrm{Sm})_{\mathrm{N}}$ ratios, which are in the range $0.20-0.37$ and $0.30-0.48$, respectively. These spinel-lherzolites (Fig. 9a and b) display a slightly depleted nature compared with the depleted mid-oceanic ridge basalt mantle (DMM; Workman \& Hart 2005), as also testified by the relatively high $\mathrm{Al}_{2} \mathrm{O}_{3} / \mathrm{SiO}_{2}$ ratios (0.064-0.079; Fig. 7). The overall geochemical features and, in particular, the high $\mathrm{Al}_{2} \mathrm{O}_{3} / \mathrm{SiO}_{2}$ ratios (Fig. 7) and $\mathrm{Al}_{2} \mathrm{O}_{3}$ and $\mathrm{TiO}_{2}$ abundances (Fig. 9a and b), are comparable with the External Ligurian Units peridotites and are clearly distinguished from the relatively more depleted Internal Ligurian Units peridotites (see Rampone et al. 1996, for details). Accordingly, the studied peridotites have REE patterns very similar to those of the External Ligurian Units lherzolites and, again, clearly different from those of the Internal Ligurian Units peridotites (Fig. 8a and b). In contrast to the Internal Ligurian Units peridotites, the External Ligurian Units lherzolites are commonly thought to represent portions of sub-continental mantle exhumed at the OCT zone (e.g. Rampone et al. 1995; Piccardo 2010; Montanini et al. 2012). 

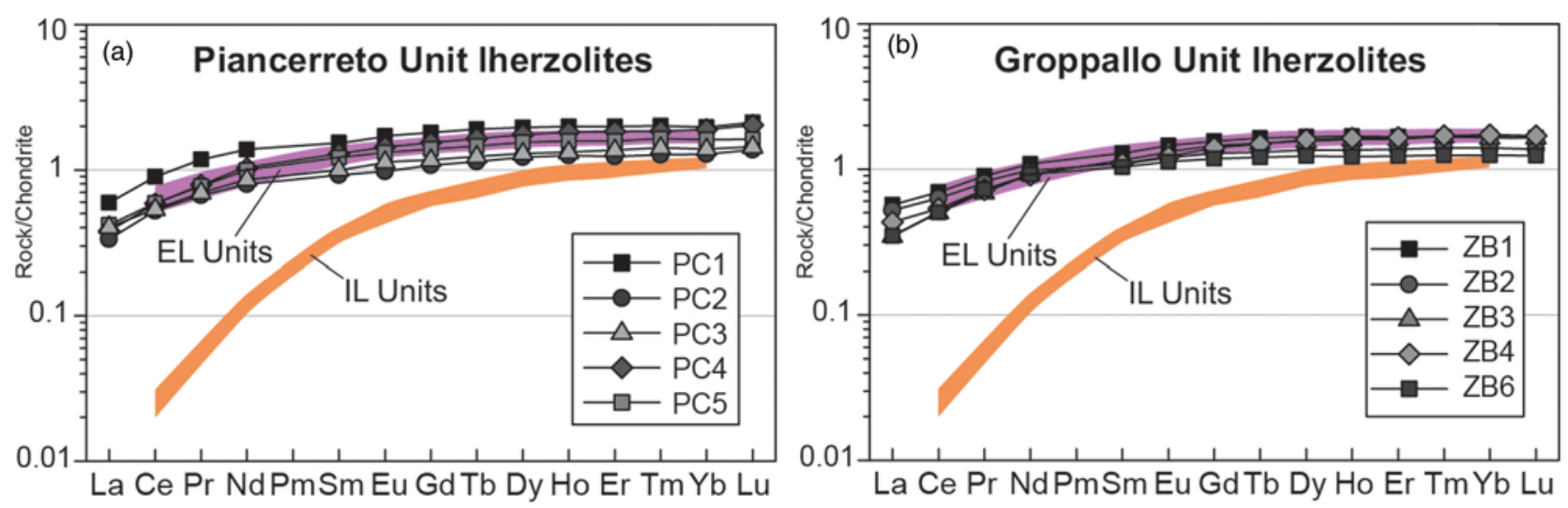

Fig. 8. Chondrite-normalized REE compositions of the blocks of upper mantle serpentinized lherzolites from the Piancerreto (a) and Groppallo (b) Units. Fields showing the compositional variation of upper mantle lherzolites from the External Ligurian (EL) and Internal Ligurian (IL) Units are shown for comparison. Data source for External Ligurian Units is Rampone et al. (1995) and Montanini et al. (2012); for Internal Ligurian Units, Rampone et al. (1996). Normalizing values are from Sun \& McDonough (1989).

\section{Discussion}

In this section we discuss the significance of our multidisciplinary data in a regional tectonic framework, focusing on the following aspects: (1) the redefinition of the stratigraphic successions of the External Ligurian Units in the MO-TH and their correlation with those in the neighbouring Voghera sector, as well as with the wellknown successions of the External Ligurian Units of the Northern Apennines (Emilia sector) in the SE; (2) the tectonostratigraphic character of the northwestern termination of the basins of the External Ligurian Units at the OCT zone of the thinned passive margin of Adria; (3) the role of the tectonosedimentary architecture of the basins of the External Ligurian Units as structural and palaeogeographical inheritance in controlling the evolution of the External Ligurian accretionary wedge during the oblique subduction stage.

\section{Redefinition of the External Ligurian Units in the MO-TH}

The undifferentiated Ligurian chaotic rock units (mélanges and broken formations) of the MO-TH (i.e. La Pietra Chaotic Complex of Dela Pierre et al. 2003; Festa et al. 2009) can be compared with those of the External Ligurian Units in the Voghera sector and/or other sectors of the Northern Apennines toward the SE (Fig. 10a and b).

The Lauriano Unit (MO-TH) shows a complete stratigraphic transition from the Santonian-Campanian Argille Varicolori (i.e. Basal Complexes) to the upper Campanian-lower Maastrichtian(?) Monte Cassio Flysch. This stratigraphic feature is comparable with that of the Cassio Unit in the Voghera sector. The local occurrence of 'exotic' tectonic blocks of Calpionella Limestone, Palombini Shale, Scabiazza Sandstone, etc. embedded within tectonic mélanges in the Argille Varicolori shows that the Lauriano Unit shares the same Basal Complexes succession with the Cassio Unit in the Voghera sector. Accordingly, both units are also characterized by the intercalation of Salti del Diavolo Conglomerates within the Argille Varicolori (Fig. 3). Both the clasts of the Salti del Diavolo Conglomerates and the 'exotic' blocks within the tectonic mélanges show lithological compositions that have close similarities to the lithostratigraphic succession of the passive margin of Adria, particularly to that exposed in the Canavese Zone to the NW of the MO-TH (Fig. 1; see Elter et al. 1966; Festa et al. 2013). This zone represents remnants of the tectonically disrupted thinned passive margin of Adria (South Alpine domain) at the OCT zone with the Ligurian-Piedmont Ocean basin (e.g. Elter et al. 1966; Ferrando et al. 2004; Barnes et al. 2014; Festa et al. 2019a).

The thickness of the Monte Cassio Flysch in the MO-TH and Voghera sector, ranging between 250 and $500 \mathrm{~m}$, gradually increases toward the SE, reaching $>1000 \mathrm{~m}$ in thickness to the SE of the Voghera sector in the Emilia Northern Apennines (e.g. Cerrina Feroni et al. 2002; Vercesi et al. 2005, 2015). This increase in thickness occurs in parallel with that one of the carbonate
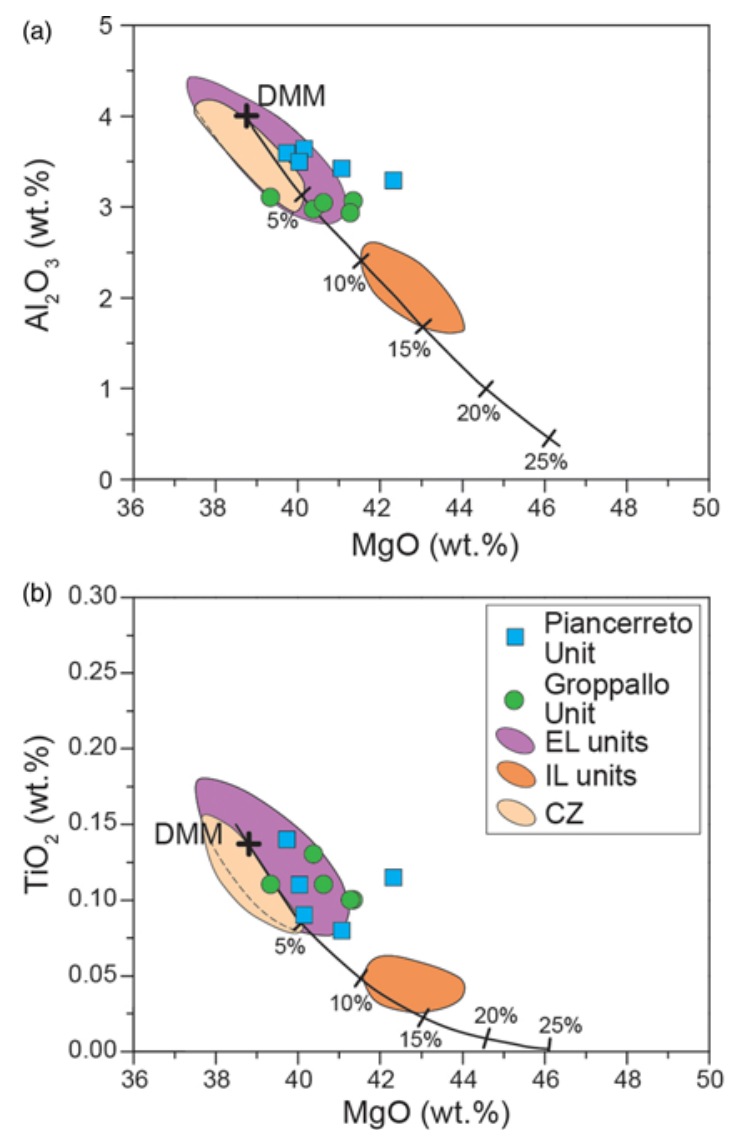

Fig. 9. Whole-rock $\mathrm{Al}_{2} \mathrm{O}_{3}$ (a) and $\mathrm{TiO}_{2}$ (b) contents v. $\mathrm{MgO}$ diagrams for the blocks of upper mantle serpentinized lherzolites from the Groppallo and Piancerreto Units. Major element contents are recalculated to $100 \%$ on a loss on ignition free basis. The DMM composition is from Workman \& Hart (2005). Lines represent the fractional partial melting trends calculated according to Niu (1997). Numbers along the lines indicate the per cent of melting. Fields showing the compositional variation of upper mantle lherzolites from the Canavese Zone (CZ), External Ligurian (EL) and Internal Ligurian (IL) Units are shown for comparison. Data source for Canavese Zone is Barnes et al. (2014); for External Ligurian Units, Rampone et al. (1995) and Montanini et al. (2012); for Internal Ligurian Units, Rampone et al. (1996). 


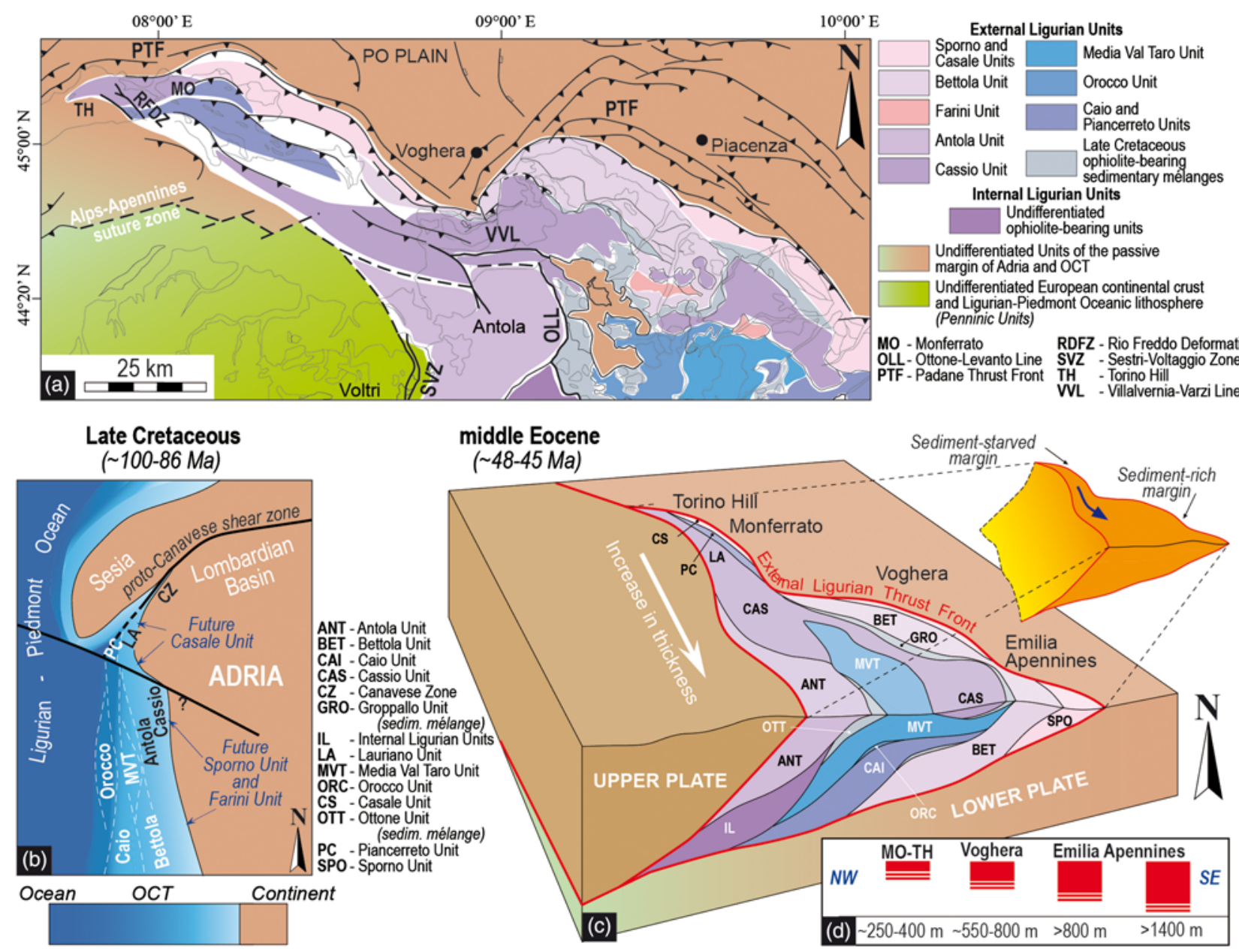

Fig. 10. (a) Structural sketch map showing the inferred correlation among the External Ligurian Units of the Northern Apennines and those of the Monferrato-Torino Hill and Voghera Sectors. (See Fig. 1 for location and key for symbols.) (b) Palaeogeographical reconstruction for early Late Cretaceous of the northwestern termination of the Ligurian-Piedmont oceanic basin at the ocean-continent transition (OCT) with the thinned passive margin of Adria (modified from Festa et al. 2019a). (c) Block diagram showing the southeastward increase in both thickness and number of units of the External Ligurian accretionary wedge in the middle Eocene (Ligurian tectonic phase). The orange 3D inset shows the lateral transition toward the SE from a sediment-starved to a sediment-rich margin (loosely based on Malatesta et al. 2013). (d) Diagram showing the lateral variation in thickness from NW to SE of the Upper Cretaceous-Paleocene-lower Eocene(?) flysches of the Cassio and Lauriano Units.

components in turbiditic layers, suggesting a gradual transition from a more proximal basin (MO-TH and Voghera), influenced by abundant arenitic turbidites, to a deeper and wider basin (Northern Apennines to the SE of Voghera), where carbonate turbidites prevailed (Fig. 10b).

In the Piancerreto and Groppallo Units, the occurrence of ultramafic rocks with close geochemical similarity to the External Ligurian Units peridotites suggests that they were sourced from the same slightly depleted sub-continental mantle at the OCT zone that existed between the Ligurian-Piedmont Ocean and the thinned Adria margin. However, in the Piancerreto Unit the lack of any evidence of a mass wasting-related block-in-matrix fabric and the occurrence of the Paleocene-lower Eocene Ottiglio clay allow us to exclude a correlation between the Piancerreto and the Groppallo Units. In fact, the Upper Cretaceous sedimentary mélange of the Groppallo Unit (i.e. Pietra Parcellara Complex), as well as those of other External Ligurian Units in the Northern Apennines (e.g. the Casanova Complex and the Monte Ragola Complex; see Marroni et al. 2010; Barbero et al. 2017), are characterized by typical polymictic argillaceous breccias alternating with coarse-grained ophiolitic sandstones. Their marked internal depositional heterogeneity represents the product of alternating blocky- to hyperconcentrated flows and cohesive-viscous flow (e.g. Ogata et al. 2014, 2019; Festa et al. 2016).
The lack of gravity-related deformation and fabric, the close association with fragments of Basal Complexes, and the occurrence of the Ottiglio clay allow us to interpret the ultramafic rocks of the Piancerreto Unit as representing tectonic slices embedded within a Basal Complex rather than gravitational olistoliths, as previous suggested by Elter et al. (1966). Moreover, the Upper Cretaceous sedimentary mélanges of Northern Apennines are never associated with a lower Cenozoic flysch deposit such as the Paleocene-lower Eocene Ottiglio clay. The latter is comparable in terms of both age and facies with the uppermost part of the Caio Unit of the Northern Apennines (i.e. Tizzano Marl; see Catanzariti \& Perilli 2015). These observations support similarities between the Piancerreto Unit and the Caio Unit, rather than to the Bettola Unit (Fig. 10a and b). In fact, in the latter the Basal Complex succession is absent, and its lower Cenozoic flysch (Val Luretta Flysch) shows characteristic pinkish marl horizons (the Poviago member, Danian-Thanetian in age). The tectonic juxtaposition of slices of ultramafic rocks with the Ottiglio clay is unconformably overlain by the middle-upper Eocene-Oligocene succession of the Tertiary Piedmont Basin, constraining their juxtaposition with the middle Eocene Ligurian Tectonic Phase (i.e. the Mesoalpine events in the Alps).

The Casale and Bettola Units represent the most external External Ligurian units in the MO-TH and Voghera sectors, respectively (Fig. 10a and c), and they both consist of stratigraphic successions 


\section{E. Barbero et al.}

lacking the Basal Complexes. The Casale Monferrato is earlymiddle Eocene in age and it lacks (1) distinctive thick beds of pinkish marls, which characterize the Val Luretta Formation in the Bettola Unit, and (2) an Upper Cretaceous-lower Paleocene Helminthoid Flysch type (i.e. Bettola Flysch). In addition, the lower part of this flysch is characterized by up to $10 \mathrm{~m}$ thick calcareous megaturbidites, which are comparable with similar turbiditic beds that characterize the Monte Sporno Flysch (Sporno Unit; see Catanzariti \& Perilli 2015, and references therein). These features collectively suggest a close affinity of the Casale Unit with the Sporno Unit of the Northern Apennines, rather than with the Bettola Unit, although the Bettola and Casale Units share the same structural position in the MO-TH and Voghera sector, respectively (Fig. 10a). The occurrence of megaturbidites in the Casale and Sporno Units suggests that they were both located in a continentward position with respect to the Piancerreto and Bettola Units, respectively (Fig. 10b). In this palaeogeographical position they were probably fed by carbonate turbidites sourced from a carbonatic platform probably existing on the Adria foreland (e.g. Vescovi 1993).

To summarize, it is worth highlighting again that the External Ligurian Units of the MO-TH can be compared with those of the Northern Apennines. In particular, the successions of the Piancerreto and Casale Units show distinctive stratigraphic similarities to those of the Caio and Sporno Units, respectively. The Lauriano Unit succession, instead, shows unambiguous stratigraphic analogies to the succession of the Cassio Unit. Therefore, in the following sections we will consider the Lauriano and Cassio Units as the same tectonic element. In addition, we will consider the Piancerreto and Casale Units as the lateral equivalent of the Caio and Sporno Units, respectively (Fig. 10b).

\section{The northwestern termination of the External Ligurian Units basin}

The redefinition and distinction of the External Ligurian Units in the MO-TH indicate that this is characterized by very few External Ligurian Units if compared with the myriad of units characterizing the External Ligurian Units in the Northern Apennines, particularly to the SE of the Voghera sector.

In the Northern Apennines to the SE of Voghera, the occurrence of a great number of External Ligurian units (Fig. 10a and c) documents the deposition within an articulated and wide basin (i.e. with respect to the MO-TH basin; see below) located at the OCT between the Ligurian-Piedmont Ocean and the thinned passive margin of Adria. Although different interpretations have been suggested, general agreement exists in distinguishing units deposited close to the Adria passive margin (e.g. Cassio, Solignano, Media Val Taro, Farini, Sporno and Antola Units or Eastern External Ligurian Units of Marroni et al. 2001) from those deposited in a relatively more ocean-ward position closer to exhumed subcontinental mantle (e.g. Caio Unit and Upper Cretaceous sedimentary mélanges or Western External Ligurian Units of Marroni et al. 2001; see also Vescovi 1993). In contrast, only three units characterize the External Ligurian Units succession in both the Voghera sector (Cassio, Groppallo and Bettola Units) and the MO-TH (Lauriano or Cassio Unit, Piancerreto or Caio Unit, and Casale or Sporno Unit). However, only the Cassio Unit can be correlated throughout both sectors (Fig. 10a and c). Some fundamental evidence indicates gradual deepening and widening of the depositional basin from the MO-TH to the Northern Apennines to the SE of Voghera (Fig. 10b). This evidence includes the gradual increase toward the SE of (1) the thickness of the Upper Cretaceous-upper Paleocene-lower Eocene(?) flysch successions of the Cassio and Lauriano Units, which range from 250-400 $\mathrm{m}$ (in the MO-TH) to $550-800 \mathrm{~m}$ (in the Voghera sector), and up to
$>1400 \mathrm{~m}$ (in the Northern Apennines to the SE of the Voghera sector; Fig. 10d), and (2) the carbonate component within turbidites of the Monte Cassio Flysch. A similar increase in thickness toward the same direction (i.e. SE) occurs for the Late Cretaceous ophiolitebearing sedimentary mélange of the Groppallo Unit, which ranges from about $150 \mathrm{~m}$ (Godiasco-western Voghera sector; Fig. 1; see Barbero et al. 2017) to more than $300 \mathrm{~m}$ (Montalto P.se-Nibbianoeastern Voghera sector; see Fig. 1), whereas the Groppallo Unit is absent in the MO-TH.

Further evidence that the Ligurian-Piedmont oceanic basin gradually widened toward the SE (present-day coordinates; Fig. 10a and b) is indirectly suggested by the gradual increase in thickness of the Ligurian accretionary wedge toward the same direction, from about $<500-1000 \mathrm{~m}$ (in the MO-TH) to $c$. $4000-6000 \mathrm{~m}$ (SE of Voghera; see Vannucchi et al. 2008; Carlini et al. 2013). In addition, the along-strike variations of the depositional basins later accreted within the Ligurian accretionary wedge is also suggested by the occurrence of different units in the same structural position (i.e. above the External Ligurian Thrust Front) from the MO-TH to the Voghera sector (Fig. 10a and c). These units are the SpornoCaio (equivalent) Units in the MO-TH and the Bettola-Groppallo Units in the Voghera sector (Fig. 10a and c).

The close affinity between the blocks embedded within the Basal Complexes of the Lauriano and Piancerreto Units and units of the Canavese Zone succession (see Elter et al. 1966; Festa et al. 2019a) suggests that these blocks were tectonically wrenched from an OCT zone (Fig. 10b). The tectonic incorporation occurred during the Ligurian Tectonic Phase (middle Eocene), as constrained by the unconformably overlying Tertiary Piedmont Basin succession. The evidence that the tectonically disrupted Palombini Shales, included within the Basal Complex of the Lauriano and Piancerreto Units in the MO-TH, are comparable with the Early Cretaceous Palombini Shales occurring at the top of the Canavese Zone succession (see Elter et al. 1966; Ferrando et al. 2004; Festa et al. 2019a) suggests that a transition existed between these two sectors (Fig. 10b). In addition, the serpentinized lherzolites from both the Piancerreto and Groppallo Units are geochemically comparable with those of the Canavese Zone (see Figs 7, 8a, b and 9a, b, and Barnes et al. 2014).

In summary, the stratigraphic and geochemical evidence outlined above indicates that the northwestern termination of the External Ligurian Units basin (i.e. the MO-TH) probably corresponded to a very narrow basin (Fig. 10b), closing toward the NW (present-day coordinates) and separating the passive margin of Adria (Canavese Zone) from the Sesia Zone (Austroalpine Units of the Western Alps; see also Festa et al. 2019a). Thus, the northwestern termination of the External Ligurian Units basin corresponded to an OCT zone where a slightly depleted sub-continental mantle was locally exposed.

\section{Role of the inherited architecture of the External Ligurian Units basin in the evolution of the Ligurian accretionary wedge}

The inherited wedge-shaped architecture of the External Ligurian Units basin (Fig. 10b and c), with a northwestward closure at the OCT zone with the Canavese Zone (i.e. present-day AlpsApennines junction), as well as the northwestward decrease in thickness of the Upper Cretaceous-lower Eocene flysch successions, may have played a significant role in controlling the structural evolution of the External Ligurian accretionary wedge during the Late Cretaceous-middle Eocene subduction stage.

Several interlinked geological, physical and mechanical factors may concur in influencing the structural evolution and dynamics of a frontal accretionary wedge. Among these factors, along an accretionary margin driven by oblique subduction, the variations of the wedge size are documented to be related to the amount of flysch 
Downloaded from http://jgs.lyellcollection.org/ by guest on July 4, 2019

Ligurian Units at Alps-Apennines junction

sediments at the trench as well as the lateral tectonic migration of sediments incorporated in the accretionary prism (Fig. 10c; Malatesta et al. 2013). The above discussed increase in thickness and facies variation of the Monte Cassio Flysch and Paleocenelower Eocene flysches toward the SE (Fig. 10d) suggest that the wedge shape of the External Ligurian Units basin probably produced a topographic gradient in the trench axis, resulting in a migration of flysch sediments toward the deeper part of the basin (i.e. toward the SE; Fig. 10c). This configuration probably produced an along-strike articulated trench showing a sediment-starved region and sectors where a wider and thicker basin formed. These different sectors probably corresponded to the MO-TH-Voghera sector and the Northern Apennines to the SE of them, respectively. Since the Late Cretaceous, this configuration and the continuing propagation of an oblique subduction may have led to the formation of an accretionary wedge increasing in thickness and elevation toward the SE (Fig. 10c), as the inherited basin configuration favoured a continuous lateral tectonic transport of flysch sediments, which were incorporated within the accretionary wedge at different times and with different velocities. This is consistent with the abovedescribed thinner v. thicker thickness of the External Ligurian accretionary wedge from the MO-TH-Voghera sector $(<500-$ $1000 \mathrm{~m}$ thick) to the Northern Apennines (c. 4000-6000 m thick).

According to numerical models on the active accretionary prism (see Malatesta et al. 2013), we suggest that in the Northern Apennines (SE of Voghera) the wider shape of the basin and the thicker trench flysch successions with respect to the MO-THVoghera sector favoured the formation of a thicker External Ligurian wedge (up to $c$. 4000-6000 m; Fig. 10c) during the early stages of subduction. In contrast, only a thin accretionary wedge formed in the sediment-starved region (MO-TH-Voghera) corresponding to the northwestern termination of the External Ligurian Units basin (Fig. 10c). Notably, in the Canavese Zone the succession ends with Lower Cretaceous Palombini Shale (see Ferrando et al. 2004; Festa et al. 2019a), and a sedimentary wedge comparable with the External Ligurian accretionary wedge is lacking. This evidence may suggest that no sedimentary wedge or only a thin accretionary wedge formed in this sector (Canavese Zone) and that External Ligurian Units-like successions may have been completely subducted. These observations clearly indicate that the inherited along-strike variations of stratigraphy, structural architecture and morphology of the OCT zone between the Ligurian-Piedmont Ocean basin and the thinned passive margin of Adria within a regional context of oblique subduction strongly controlled the formation and evolution of the External Ligurian accretionary wedge.

\section{Concluding remarks}

This study documents that the undifferentiated chaotic Ligurian Units of the MO-TH (Alps-Apennines junction) consist of three different units that are comparable with or show strong similarities to the Cassio, Caio and Sporno Units of the External Ligurian Units of the Northern Apennines. Their internal stratigraphy reflects the character of units deposited in an OCT zone between the northwestern termination of the Ligurian-Piedmont oceanic basin and the thinned passive margin of Adria. The remnants of the latter are inferred to correspond to the Canavese Zone, at present to the NW of the MO-TH, as documented by the close similarity between blocks and clasts embedded within the Basal Complexes and the lithostratigraphy of the Canavese Zone.

The comparisons between the External Ligurian Units in the MO$\mathrm{TH}$ and those in the Northern Apennines sectors (e.g. the Voghera sector and Emilia Apennines to the SE) show that significant variations in thickness and stratigraphic architecture occur in the External Ligurian successions from the MO-TH to the Northern
Apennines to the SE of Voghera. This evidence suggests a wedge shape for the External Ligurian Units basin and its gradual closure toward the north between the Sesia Zone (future Austroalpine domain) and the passive margin of Adria. The inherited wedgeshaped architecture of the External Ligurian Units basin and its control on the Late Cretaceous-early Eocene flysch deposition at the trench strongly conditioned the structural architecture and evolution of the External Ligurian accretionary wedge during the subduction stage. This inherited configuration coupled with the propagation of an oblique subduction favoured the formation of an accretionary wedge increasing in thickness and elevation toward the $\mathrm{SE}$, from the MO-TH to the Emilian Northern Apennines.

Our results furnish important constraints for the palaeogeographical reconstruction of the northwestern termination of the LigurianPiedmont oceanic basin at the Alps-Apennines junction. Furthermore, our results provide significant information for a better understanding of the role of inherited along-strike variations (stratigraphy, structural architecture and morphology) of OCT zones in controlling the location of subduction-zone development, and the subsequent structural-morphological evolution of frontal accretionary wedges.

Acknowledgements We would like to express our sincere thanks to A. Montanini and M. Carlini for their constructive and thorough reviews, from which we have benefited greatly in revising our paper. We thank G. Balestro, S. Cavagna, A. Centelli, G. Codegone, S. De Caroli, F. Dela Pierre, A. Irace, M. Marroni, L. Pandolfi, F. Panini, F. Piana, F. Remitti and A. Succo for insightful discussion on various aspects of the evolution of the geology of the Northern Apennines and the Western Alps, which were most helpful for the formulation of our ideas presented in this paper. R. Tassinari is acknowledged for technical support with chemical analyses.

Funding The research has been supported by research grants from the Università di Torino (Ricerca Locale 'ex 60\%' 2014-2018) to A.F., from the Italian Ministry of Education, University and Research ('Finanziamento annuale individuale delle attività base di ricerca' 2017) to A.F., and from the University of Ferrara (FIR-2016 Project) to E.S.

Scientific editing by Kei Ogata

\section{References}

Argnani, A. 2012. Plate motion and the evolution of Alpine Corsica and Northern Apennines. Tectonophysics, 579, 207-219, https://doi.org/10.1016/j.tecto. 2012.06.010

Balestro, G., Festa, A., Dilek, Y. \& Tartarotti, P. 2015. Pre-Alpine extensional tectonics of a peridotite localized oceanic core complex in the late Jurassic, high-pressure Monviso ophiolite (Western Alps). Episodes, 38, 266-282, https://doi.org/10.18814/epiiugs/2015/v38i4/82421

Balestro, G., Festa, A., Borghi, A., Castelli, D. \& Gattiglio, M. 2018. Role of Late Jurassic intra-oceanic structural inheritance in the Alpine tectonic evolution of the Monviso meta-ophiolite Complex (Western Alps). Geological Magazine, 155, 233-249, https://doi.org/10.1017/S0016756817000553

Barbero, E., Festa, A., Fioraso, G. \& Catanzariti, R. 2017. Geology of the Curone and Staffora Valleys (NW Italy): field constraints for the Late CretaceousPliocene tectono-stratigraphic evolution of Northern Apennines. Journal of Maps, 13, 879-891, https://doi.org/10.1080/17445647.2017.1398114

Barnes, J.D., Beltrando, M., Lee Cin-Ty, A., Cisneros, M., Loewy, S. \& Chin, E. 2014. Geochemistry of Alpine serpentinites from rifting to subduction: a view across paleogeographic domains and metamorphic grade. Chemical Geology, 389, 29-47, https://doi.org/10.1016/j.chemgeo.2014.09.012

Beccaluva, L., Macciotta, G., Piccardo, G.B. \& Zeda, O. 1984. Petrology of lherzolitic rocks from the Northern Apennine ophiolites. Lithos, 17, 299-316, https://doi.org/10.1016/0024-4937(84)90027-6

Bettelli, G., Bonazzi, U. \& Panini, F. 1989. Schema introduttivo alla geologia delle Liguridi dell'Appennino Modenese e delle aree limitrofe. Memorie della Società Geologica Italiana, 39, 91-125.

Bonsignore, G., Bortolami, G. et al. 1969. Note Illustrative dei Fogli 56-57, Torino-Vercelli della Carta Geologica d'Italia alla scala 1:100,000. Servizio Geologico d'Italia, Roma, 1-96.

Bracciali, L., Marroni, M., Pandolfi, L. \& Rocchi, S. 2007. Geochemistry and petrography of Western Tethys Cretaceous sedimentary covers (Corsica and Northern Apennines): From source areas to configuration of margins. In: Arribas, J., Johnsson, M.J. \& Critelli, S. (eds) Sedimentary Provenance and Petrogenesis: Perspectives from Petrography and Geochemistry. Geological Society of America, Special Papers, 420, 73-93, https://doi.org/10.1130/2006. 2420(06) 


\section{E. Barbero et al.}

Carlini, M., Artoni, A. et al. 2013. Exhumation and reshaping of far-travelled/ allochthonous tectonic units in mountain belts. New insights for the relationships between shortening and coeval extension in the western Northern Apennines (Italy). Tectonophysics, 608, 267-287, https://doi.org/ 10.1016/j.tecto.2013.09.029

Catanzariti, R. \& Perilli, N. 2011. Chronostratigraphic framework of the External Ligurides (Late Cretaceous, Northern Apennines, Italy) based on calcareous nannofossils. Ofioliti, 36, 37-57.

Catanzariti, R. \& Perilli, N. 2015. Calcareous nannofossils biostratigraphy of Paleocene to middle Eocene successions (Tertiary Flysch Auctt.) of the Northern Apennines. Rivista Italiana di Paleontologia e Stratigrafia, 121, 195-215, https://doi.org/10.13130/2039-4942/6513

Cerrina Feroni, A., Ottria, G. \& Vescovi, P. 2002. Note Illustrative della Carta Geologica d'Italia alla scala 1:50.000, Foglio 217 Neviano degli Arduini. Servizio Geologico d'Italia. SELCA, Firenze.

Clift, P. \& Vannucchi, P. 2004. Controls on tectonic accretion versus erosion in subduction zones: implications for the origin and recycling of the continental crust. Reviews of Geophysics, 42, RG2001, https://doi.org/10.1029/ 2003RG000127

Cobianchi, M., Piccin, A. \& Vercesi, P.L. 1994. La Formazione di Val Luretta (Appennino Piacentino): Nuovi dati litostratigrafici e biostratigrafici. Atti Ticinensi di Scienze della Terra, 37, 235-262.

Cobianchi, M., Piccin, A. \& Vercesi, P.L. 1995. Nota preliminare sulla biostratigrafia della Formazione di Val Luretta nell'Appennino pavesepiacentino. Atti Ticinensi di Scienze della Terra (Serie Speciale), 3, 83-88.

Codegone, G., Festa, A., Dilek, Y. \& Pini, G.A. 2012. Small-scale polygenetic mélanges in the Ligurian accretionary complex, Northern Apennines, Italy, and the role of shale diapirism in superposed mélange evolution in orogenic belts. Tectonophysics, 568-569, 170-184, https://doi.org/10.1016/j.tecto. 2012.02.003

Coward, M.P. \& Dietrich, D. 1989. Alpine tectonics - an overview. In: Coward, M.P., Dietrich, D. \& Park, R.G. (eds) Alpine Tectonics. Geological Society, London, Special Publications, 45, 1-29, https://doi.org/10.1144/GSL.SP.1989. 045.01.01

Dela Pierre, F., Piana, F. et al. 2003. Note Illustrative della Carta Geologica d'Italia alla Scala 1:50,000, Foglio 157 'Trino' [including 1 geological map at 1:50,000 scale]. Agenzia per la Protezione dell'Ambiente e per i Servizi Tecnici (APAT), Dipartimento Difesa del Suolo, Rome. Ed. Litografia Geda, Nichelino (TO).

Elter, P. 1975. L'Ensemble Ligure. Bulletin dé la Société Géologique de France, 17, 984-997, https://doi.org/10.2113/gssgfbull.S7-XVII.6.984

Elter, P. \& Marroni, M. 1991. Le Unità Liguri dell'Appennino Settentrionale: sintesi dei dati e nuove interpretazioni. Memorie Descrittive della Carta Geologica d'Italia, 46, 131-138.

Elter, G., Elter, P., Sturani, P. \& Weidmann, M. 1966. Sur la prolongation du domaine ligure de l'Apennin dans le Monferrat et les Alpes et sur l'origine de la Nappe de la Simme s.l. des Préalpes romandes et chaiblaisiennes. Archives des Sciences, Géneve, 176, 279-377.

Elter, P., Marroni, M., Molli, G. \& Pandolfi, L. 1991. Le caratteristiche stratigrafiche del Complesso di M. Penna/Casanova (Alta Val di Trebbia, Appennino Settentrionale). Atti Ticinensi di Scienze della Terra, 34, 97-106.

Ferrando, S., Bernoulli, D. \& Compagnoni, R. 2004. The Canavese Zone (Internal Western Alps): a distal margin of Adria. Schweizerische Mineralogische und Petrographische Mitteilungen, 84, 237-256.

Festa, A. \& Codegone, G. 2013. Geological map of the External Ligurian Units in western Monferrato (Tertiary Piedmont Basin, NW Italy). Journal of Maps, 9 , 84-97, https://doi.org/10.1080/17445647.2012.757711

Festa, A., Piana, F., Dela Pierre, F., Malusà, M.G., Mosca, P. \& Polino, R. 2005. Oligocene-Neogene kinematic constraints in the retroforeland basin of the Northwestern Alps. Rendiconti della Società Geologica Italiana (Nuova Serie), 1, 107-108.

Festa, A., Dela Pierre, F. et al. 2009. Note Illustrative della Carta Geologica d'Italia alla Scala 1:50,000, Foglio 156 'Torino Est': Nichelino, Italy [including 1 geological map at 1:50,000 scale and illustrative notes]. Istituto Superiore per la Protezione e la Ricerca Ambientale (ISPRA), Roma. Litografia Geda, Nichelino (TO)

Festa, A., Dilek, Y., Codegone, G., Cavagna, S. \& Pini, G.A. 2013. Structural anatomy of the Ligurian accretionary wedge (Monferrato, NW Italy), and evolution of superposed mélanges. Geological Society of America Bulletin, 125, 1580-1598, https://doi.org/10.1130/B30847.1

Festa, A., Fioraso, G., Bissacca, E. \& Petrizzo, M.R. 2015. Geology of the Villalvernia-Varzi Line between Scrivia and Curone valleys (NW Italy). Journal of Maps, 11, 39-55, https://doi.org/10.1080/17445647.2014.959569

Festa, A., Ogata, K., Pini, G.A., Dilek, Y. \& Alonso, J.L. 2016. Origin and significance of olistotromes in the evolution of orogenic belts: a global synthesis. Gondwana Research, 39, 180-203, https://doi.org/10.1016/j.gr. 2016.08.002

Festa, A., Dilek, Y., Mittempergher, S., Ogata, K., Pini, G.A. \& Remitti, F. 2018. Does subduction of mass transport deposits (MTDs) control seismic behavior of shallow-level megathrust at convergent margins? Gondwana Research, 60 , 186-193, https://doi.org/10.1016/j.gr.2018.05.002

Festa, A., Balestro, G., Borghi, S., De Caroli, S. \& Succo, A. 2019a. The role of structural inheritance in continental break-up and exhumation of Alpine Tethyan mantle (Canavese Zone, Western Alps). Geoscience Frontiers, https://doi.org/10.1016/j.gsf2018.11.007
Festa, A., Pini, G.A., Ogata, K. \& Dilek, Y. 2019b. Diagnostic features and fieldcriteria in recognition of tectonic, sedimentary and diapiric mélanges in orogenic belts and exhumed subduction-accretion complexes. Gondwana Research, https://doi.org/10.1016/j.gr.2019.01.003

Geersen, J. 2019. Sediment-starved trenches and rough subducting plates are conductive to tsunami earthquakes. Tectonophysics, 762, 28-44, https://doi. org/10.1016/j.tecto.2019.04.024

Hart, S.R. \& Zindler, A. 1986. In search of the bulk Earth composition. Chemical Geology, 57, 247-267, https://doi.org/10.1016/0009-2541(86)90053-7

Heuret, A., Conrad, C.P., Funiciello, F., Lallemand, S. \& Sandri, L. 2012. Relation between subduction megathrust earthquakes, trench sediment thickness and upper plate strain. Geophysical Research Letters, 39, L05304, https://doi.org/10.1029/2011GL050712

Jagoutz, E., Palme, H. et al. 1979. The abundances of major and trace elements in the Earth's mantle as derived from primitive ultramafic nodules. In Proceedings of 10th Lunar and Planetary Science Conference, Houston, TX, 19-23 March, 1979, 2, Pergamon Press, New York, 2031-2050.

Lovari, D. 1912. Descrizione dei giacimenti calcareo-marnosi delle colline di Casale Monferrato ed alcuni cenni sulla loro utilizzazione per la produzione della calce idraulica e del cemento. Ministero Agricoltura Industria e Commercio, Ispettorato Miniere, Roma.

Malatesta, C., Gerya, T., Crispini, L., Federico, L. \& Capponi, G. 2013. Oblique subduction modelling indicates along-trench tectonic transport of sediments. Nature Communications, 4, 2456, https://doi.org/10.1038/ncomms3456

Marotta, A.M., Roda, M., Conte, K. \& Spalla, M.I. 2018. Thermo-mechanica numerical model of the transition from continental rifting to oceanic spreading: the case study of the Alpine Tethys. Geological Magazine, $\mathbf{1 5 5}$, 250-279, https://doi.org/10.1017/S0016756816000856

Marroni, M. \& Pandolfi, L. 1996. The deformation history of an accreted ophiolite sequence: The Internal Liguride units (Northern Apennines, Italy). Geodinamica Acta, 9, 13-29, https://doi.org/10.1080/09853111.1996.11417260

Marroni, M. \& Pandolfi, L. 2007. The architecture of the Jurassic LigurePiemontese oceanic basin: Tentative reconstruction along the Northern Apennine-Alpine Corsica transect. International Journal of Earth Sciences, 96, 1059-1078, https://doi.org/10.1007/s00531-006-0163-x

Marroni, M. \& Tribuzio, R. 1996. Gabbro-derived granulites from external Liguride units (Northern Apennines, Italy): Implications for the rifting processes in the western Tethys. Geologische Rundschau, 85, 239-249, https://doi.org/10.1007/BF02422231

Marroni, M., Molli, G., Montanini, A. \& Tribuzio, R. 1998. The association of continental crust rocks with ophiolites (Northern Apennines, Italy): Implications for the continent-ocean transition. Tectonophysics, 292, 43-66, https://doi.org/10.1016/S0040-1951(98)00060-2

Marroni, M., Molli, G., Ottria, G. \& Pandolfi, L. 2001. Tectono-sedimentary evolution of the External Liguride units (Northern Apennines, Italy): insights in the pre-collisional history of a fossil ocean-continent transition zone. Geodinamica Acta, 14, 307-320, https://doi.org/10.1080/09853111.2001.11432449

Marroni, M., Pandolfi, L. \& Meneghini, F. 2004. From accretion to exhumation in a fossil accretionary wedge: a case history from Gottero Unit (Northern Apennines, Italy). Geodinamica Acta, 17, 41-53, https://doi.org/10.3166/ga. 17.41-53

Marroni, M., Meneghini, F. \& Pandolfi, L. 2010. Anatomy of the LigurePiemontese subduction system: evidence from Late Cretaceous-middle Eocene convergent margin deposits in the Northern Appennines, Italy. International Geology Review, 52, 1160-1192, https://doi.org/10.1080/ 00206810903545493

Marroni, M., Meneghini, F. \& Pandolfi, L. 2017. A revised subduction inception model to explain the Late Cretaceous, double-vergent orogen in the precollisional western Tethys: Evidence from the Northern Apennines. Tectonics, 36, 2227-2249, https://doi.org/10.1002/2017TC004627

Molli, G. \& Malavieille, J. 2011. Orogenic processes and the Corsica/Apennines geodynamic evolution: insights from Taiwan. International Journal of Earth Sciences, 100, 1207-1224, https://doi.org/10.1007/s00531-010-0598-y

Molli, G., Crispini, L., Mosca, P., Piana, P. \& Federico, L. 2010. Geology of the Western Alps-Northern Apennine junction area: a regional review. Journal of the Virtual Explorer, 36, https://doi.org/10.3809/jvirtex.2010.00215

Montanini, A. 1997. Mafic granulites in the Cretaceous sedimentary melanges from the northern Apennines (Italy): petrology and tectonic implications. Schweizerische Mineralogische und Petrographische Mitteilungen, 77, 43-64.

Montanini, A., Tribuzio, R. \& Anczkiewicx, R. 2006. Exhumation history of a garnet pyroxenite-bearing mantle section from a continent-ocean transition (Northern Apennine ophiolites, Italy). Journal of Petrology, 47, 1943-1971, https://doi.org/10.1093/petrology/eg1032

Montanini, A., Tribuzio, R. \& Thirlwall, M. 2012. Garnet clinopyroxenite layers from the mantle sequences of the Northern Apennine ophiolites (Italy): evidence for recycling of crustal material. Earth and Planetary Science Letters, 351-352, 171-181, https://doi.org/10.1016/j.eps1.2012.07.033

Mosca, P., Polino, R., Rogledi, S. \& Rossi, M. 2010. New data for the kinematic interpretation of the Alps-Apennines junction (northwestern Italy) International Journal of Earth Sciences, 99, 833-849, https://doi.org/10. 1007/s00531-009-0428-2

Mutti, E., Papani, L., Di Biase, D., Davoli, G., Mora, S., Segadelli, S. \& Tinterri, R. 1995. Il Bacino Terziario Epimesoalpino e le sue implicazioni sui rapporti tra Alpi ed Appennino. Memorie della Società Geologica di Padova, 47, 217-244. 


\section{Ligurian Units at Alps-Apennines junction}

Niu, Y. 1997. Mantle melting and melt extraction processes beneath ocean ridges: evidence from abyssal peridotites. Journal of Petrology, 38, 1047-1074, https://doi.org/10.1093/petroj/38.8.1047

Ogata, K., Mountjoy, J.J., Pini, G.A., Festa, A. \& Tinterri, E. 2014. Shear zone liquefaction in mass transport deposit emplacement: a multi-scale integration of seismic reflection and outcrop data. Marine Geology, 356, 50-64, https:// doi.org/10.1016/j.margeo.2014.05.001

Ogata, K., Festa, A., Pini, G.A., Pogačnik, Ž \& Lucente, C.C. 2019. Substrate deformation and incorporation in sedimentary mélanges (olistostromes) Examples from the northern Apennines (Italy) and northwestern Dinarides (Slovenia). Gondwana Research, https://doi.org/10.1016/j.gr.2019.03.001

Panini, F., Fioroni, C., Fregni, P. \& Bonacci, M. 2002. Le rocce caotiche dell'Oltrepo Pavese: Note illustrative della Carta Geologica dell'Appennino vogherese tra Borgo Priolo e Ruino. Atti Ticinenesi di Scienze della Terra, 43, 83-109.

Panini, F., Fioroni, C. \& Fregni, P. 2006. Geologia dell'area di Varzi (Appennino Vogherese): note preliminari. Atti Ticinesi di Scienze della Terra 45, 43-59.

Piana, F. 2000. Structural features of Western Monferrato (Alps-Apennines junction zone, NW Italy). Tectonics, 19, 943-960, https://doi.org/10.1029/ 2000TC900013

Piana, F. \& Polino, R. 1995. Tertiary structural relationships between Alps and Apennines: The critical Torino Hill and Monferrato area: Northwestern Italy. Terra Nova, 7, 138-143, https://doi.org/10.1111/j.1365-3121.1995.tb00682.x

Piccardo, G.B. 2010. The evolution of the lithospheric mantle during Mesozoic rifting in the Ligure-Piedmontese Domain. Journal of the Virtual Explorer, 36, https://doi.org/10.3809/jvirtex.2010.00219.

Piccardo, G.B., Rampone, E., Romairone, A., Scambelluri, M., Tribuzio, R. \& Beretta, C. 2001. Evolution of the Ligurian Tethys: inference from petrology and geochemistry of the Ligurian Ophiolites. Periodico di Mineralogia, 70, 147-192.

Polino, R., Dal Piaz, G.V. \& Gosso, G. 1990. Tectonic erosion at the Adria margin and accretionary processes for the Cretaceous orogeny of the Alps. Mémoires de la Société Géologique de France, 156, 345-367.

Principi, G. \& Treves, B. 1984. Il sistema corso-appenninico come prisma d'accrezione. Riflessi sul problema generale del limite Alpi-Appennini. Memorie della Società Geologica Italiana, 28, 549-576.

Principi, G., Bortolotti, V. et al. 2004. The pre-orogenic volcano-sedimentary covers of the Western Tethys oceanic basins: a review. Ofioliti, 29, 177-211, https://doi.org/10.4454/ofioliti.v29i2.213

Rampone, E., Hofmann, A.W., Piccardo, G.B., Vannucci, R., Bottazzi, P. \& Ottolini, L. 1995. Petrology, mineral and isotope geochemistry of the external Liguride peridotites (northern Apennines, Italy). Journal of Petrology, 36, 81-105, https://doi.org/10.1093/petrology/36.1.81

Rampone, E., Hofmann, A.W., Piccardo, G.B., Vannucci, R., Bottazzi, P. \& Ottolini, L. 1996. Trace element and isotope geochemistry of depleted peridotites from an N-MORB type ophiolite (Internal Liguride, N.Italy) Contributions to Mineralogy and Petrology, 123, 61-76, https://doi.org/10. 1007/s004100050143

Rampone, E., Borghini, G. \& Basch, V. 2019. Melt migration and melt-rock reaction in the Alpine-Apennine peridotites: Insights on mantle dynamics in extending lithosphere. Geoscience Frontiers, https://oi.org/10.1016/j.gsf. 2018.11.001

Remitti, F., Vannucchi, P., Bettelli, G., Fantoni, L., Panini, F. \& Vescovi, P. 2011. Tectonic and sedimentary evolution of the frontal part of an ancient subduction complex at the transition from accretion to erosion: the case of the Ligurian wedge of the northern Apennines, Italy. Geological Society of America Bulletin, 123, 51-70, https://doi.org/10.1130/B30065.1

Roda, M., De Salvo, F., Zucali, M. \& Spalla, M.I. 2018. Structural and metamorphic evolution during tectonic mixing: is the Rocca Canavese Thrust Sheet (Italian Western Alps) a subduction related mélange? Italian Journal of Geosciences, 137, 311-329, https://doi.org/10.3301/JJG.2018.17

Rosenbaum, G., Lister, G.S. \& Duboz, C. 2002. Relative motions of Africa, Iberia and Europe during Alpine orogeny. Tectonophysics, 359, 117-129, https://doi.org/10.1016/S0040-1951(02)00442-0
Saccani, E., Dilek, Y., Marroni, M. \& Pandolfi, L. 2015. Continental margin ophiolites of Neotethys: Remnants of ancient ocean-continent transition zone (OCTZ) lithosphere and their geochemistry, mantle sources and melt evolution patterns. Episodes, 38, 230-249, https:/doi.org/10.18814/epiiugs/ 2015/v38i4/82418

Saccani, E., Dilek, Y. \& Photiades, A. 2017. Time-progressive mantle-melt evolution and magma production in a Tethyan marginal sea: A case study of the Albanide-Hellenide ophiolites. Lithosphere, 10,35-53, https://doi.org/10. 1130/L602.1

Saccani, E., Delavari, M., Dolati, A., Marroni, M., Pandolfi, L., Chiari, M. \& Barbero, E. 2018. New insights into the geodynamics of Neo-Tethys in the Makran area: Evidence from age and petrology of ophiolites from the Coloured Mélange Complex (SE Iran). Gondwana Research, 62, 306-327, https://doi.org/10.1016/j.gr.2017.07.013

Sacco, F. 1935. Note Illustrative della Carta Geologica d'Italia alla Scala 1:100,000, Fogli di Torino, Vercelli, Mortara, Carmagnola, Asti, Alessandria, Cuneo, Ceva, Genova N. e Voghera O. Costituenti il Bacino Terziario del Piemonte. Ministero delle Corporazioni, Regio Ufficio Geologico di Roma, Rome.

Sanfilippo, A. \& Tribuzio, R. 2011. Melt transport and deformation history in a nonvolcanic ophiolitic section, northern Apennines, Italy: Implications for crustal accretion at slow spreading settings. Geochemistry, Geophysics, Geosystems, 12, Q0AG04, https://doi.org/10.1029/2010GC003429

Spalla, M.I., Zanoni, D., Marotta, A.M., Rebay, G., Roda, M., Zucali, M. \& Gosso, G. 2014. The transition from Variscan collision to continental break-up in the Alps: insights from the comparison between natural data and numerical model predictions. In: Schulmann, K., Martínez Catalán, J.R., Lardeaux, J.M., Janoušek, V. \& Oggiano, G. (eds) The Variscan Orogeny: Extent, Timescale and the Formation of the European Crust. Geological Society, London, Special Publications, 405, 363-400, https://doi.org/10.1144/SP405.11

Sun, S.S. \& McDonough, W.F. 1989. Chemical and isotopic systematics of oceanic basalts: implications for mantle composition and processes. In: Saunders, A.D. \& Norry, M.J. (eds) Magmatism in the Ocean Basins. Geological Society, London, Special Publications, 42, 313-345, https://doi. org/10.1144/GSL.SP.1989.042.01.19

Tribuzio, R., Thirlwall, M.F. \& Vannucci, R. 2004. Origin of the gabbroperidotite association from the Northern Apennine ophiolites (Italy). Journal of Petrology, 45, 1109-1124, https://doi.org/10.1093/petrology/egh006

Vannucchi, P., Remitti, F. \& Bettelli, G. 2008. Geological record of fluid flow and seismogenesis along an erosive subducting plate boundary. Nature, $\mathbf{4 5 1}$, 699-703, https://doi.org/10.1038/nature06486

Vercesi, P.L. \& Cobianchi, M. 1998. Stratigrafia di un frammento di margine continentale giurassico: la successione di C.se Caldarola (Appennino Piacentino). Bollettino della Società Geologica Italiana, 117, 537-554.

Vercesi, P.L., Piccin, A. et al. 2005. Carta Geologica d'Italia alla scala 1:50.000. Foglio 179 'Ponte dell'Olio' [including 1 Geological Map at 1:50,000 scale]. Agenzia per la Protezione dell'Ambiente e per i Servizi Tecnici (APAT), Dipartimento Difesa del Suolo, Rome.

Vercesi, P.L., Falletti, P., Pasquini, C., Papani, L., Perotti, C. \& Tucci, G. 2015 Carta Geologica d'Italia alla scala 1:50.000. Foglio 178 'Voghera' [including 1 Geological Map at 1:50,000 scale]. Agenzia per la Protezione dell' Ambiente e per i Servizi Tecnici (APAT), Dipartimento Difesa del Suolo, Rome.

Vescovi, P. 1993. Schema evolutivo per le Liguridi dell'Appennino Settentrionale. Atti Ticinensi di Scienze della Terra, 36, 89-112.

Vescovi, P., Fornaciari, E., Rio, D. \& Valloni, R. 1999. The Basal Complex stratigraphy of the helminthoid Monte Cassio Flysch: a key to the eo-alpine tectonics of the Northern Apennines. Rivista Italiana di Paleontologia e Stratigrafia, 105, 101-128.

Workman, R.K. \& Hart, S.R. 2005. Major and trace element composition of the depleted MORB mantle (DMM). Earth and Planetary Science Letters, 231 , 53-72, https://doi.org/10.1016/j.eps1.2004.12.005

Zanchetta, S., Garzanti, E., Doglioni, C. \& Zanchi, A. 2012. The Alps in the Cretaceous: A doubly vergent pre-collisional orogeny. Terra Nova, 24, 351-356, https://doi.org/10.1111/j.1365-3121.2012.01071.x 